\title{
ALIGNMENT OF SPATIAL, TRANSPORTATION AND ENVIRONMENTAL PLANNING: PRACTICES UNDERPINNING STRATEGIC APPROACHES IN DEVELOPING COUNTRIES
}

\author{
ILSE MARIA SCHOEMAN \& CAREL BENJAMIN SCHOEMAN \\ North West University, South Africa
}

\begin{abstract}
The debate and discourse for the need to align spatial planning, transportation planning and environmental management strategically, functionally and operationally to inform modelling is ongoing internationally since the early 2000s. This incorporates the articulation of the planning instruments used by the professionals within these functional fields and the way in which it is coordinated and applied as to enhance strategic planning and decision making.

With the approval of the Spatial Planning and Land Use Management Act (SPLUMA) (Act 16 of 2013) and the SPLUMA Regulations (23 March 2015) in South Africa, the last bastion of 'Apartheid' planning legislation from the previous political dispensation was reformed. Although this process is still legislatively being finalized at provincial and municipal levels of government through adapting new transformation structures, guidelines, policies and regulations, the opportunity exists to assess the impacts of alignment to improve strategic planning, modelling, coordination and decision making.

In this chapter the alignment between the policy and legislative frameworks, guidelines, processes and the need for integration will be discussed. The approach presented in this paper will especially guide planning within developing countries based on the learning experiences from spatial systems in developed countries.
\end{abstract}

Keywords: integrated planning, spatial planning, transportation planning, environmental management, transformation processes.

\section{INTRODUCTION TO ALIGNMENT AND INTEGRATION}

Internationally, spatial planning and its alignment and interface with transportation planning and environmental management form the focal point in attaining and promoting sustainable planning, development and delivery. The issue of misalignment between various levels of government in developing countries and more specifically South Africa dates back to 1910 during the formation of the Union of South Africa from its colonial inheritance. However, since democratization in 1994 and the promulgation of the Constitution of South Africa (Act 108 of 1996) [1], resulting in the establishment of three distinct spheres of government, the lack of alignment and integration became more prevalent.

In order to understand the context of this chapter, one should consider what is implied by the concept of 'alignment'? From a governmental and planning perspective, 'alignment' includes the articulation and optimization of processes contained in goals and objectives (inclusive of communication, involvement, engagement, support and capacity-building activities) to ensure efficient and effective outcomes through optimal application of planning instruments in plan formulation and decision making, as provided for in different policies and legislation across all levels of government.

'Integration' thus refers to processes and methodological approaches and procedures followed in planning processes through application of specific instruments and/or planning tools. Alignment and integration are often used inter-changeably. Modelling to be effective 
should thus be applied to alternative focuses such as spatial planning, transportation planning and environmental management.

The dilemma of alignment and integration, or the lack thereof, was also experienced internationally in planning processes in developed countries. The best example from international practice relates to the approach to assess integration in Europe of policy and research. Geerlings and Stead [2] state that 'policy' integration should include the following dynamic focuses:

- Vertical integration between different levels of government.

- Horizontal integration between sectors or professions in one organization.

- Inter-territorial integration between neighbouring authorities or authorities with a shared interest in infrastructure or resources.

- Intra-sectoral integration between different sections or professions.

Stead et al. [3] identify the following hierarchical foci in dealing with an approach towards integration: co-operation at the lowest level consisting of dialogue and information; co-ordination, coherence and consistency with emphasis on transparency; integration and joined-up policy approaches inclusive of dialogue and avoiding of conflicts. These are supported by inter-organizational coordination; inter-organizational collaboration; intergovernmental management and network management.

Essentially, many of these concepts are present in strategic planning instruments in South Africa such as the Integrated Development Plan (IDP) and environmental management processes such as Strategic Environmental Assessment (SEA) and Environmental Management Frameworks (EMFs) and related practices and planning processes. The realization of optimal alignment and integration approaches between strategic and planning instruments (in developing as well as developed countries) represents a main challenge. May et al. [4] also addressed the issues of integration of policy instruments as a challenge within urban transport policy.

In South Africa, the White Paper on Spatial Planning and Land Use Management [5] states that land-use and development decisions must promote a harmonious relationship between the built and the natural environment while ensuring that land development is sustainable over a longer term. Claasens [6] was one of the first planners to confront the interface between spatial planning, development planning and conservation in promoting sustainable development. Sowman and Brown [7] developed a framework to assist integration between the IDP process and environmental management in order to promote sustainability. Berrisford and Kihato [8] concluded that defining the relationship between planning and the environmental laws is a question that is persistently dogged by planning and environmental practitioners in South Africa. This view is derived from research by Sowman [9] and Todes [10] for a spatial system being classified in a developing country.

Todes et al. [11] address the relationship between planning and environmental management in South Africa based on a case study for the provincial spatial system of KwaZulu-Natal. From the outcome, specific research elements inclusive of purpose, method and evidence base are identified to demonstrate the relationship between planning and environmental management across spheres of government, tools applied and types of plans. Of importance to this chapter is the conclusion that the relationships between planning and environmental management in South Africa are complex and also the result of formal systems in planning and environment inclusive of elements such as agency, power practice and discourse. This describes the dynamics within developing countries and/or spatial systems accurately.

Todes et al. [11] isolate the following core components in assessing integration: 
- The purposes of planning.

- Tools and mechanisms applied.

- Distribution of responsibilities.

- Resources and capacity.

- Networks, capacity and discourse.

In this regard, the work by Schoeman [12] on the interface between urban and regional planning, environmental management and transportation planning should also be noted. The deduction by Todes et al. [11] is based on the work developed by Vigar et al. [13]. Todes et al. [11] conclude, in general, that there is a need for greater integration between planning and environmental management in context with the assessment components identified earlier. It is concluded that integration is more than a technical process. At the same time, the legal system, forms of planning and environmental management and practical considerations are all fulfilling an important role in promoting inclusivity in integration. This may be attained through merging of functions; incorporation of foci, institutional integration, and coordination of vertical and horizontal linkages.

Retief and Rossouw [14] also address the theme of alignment and integration from a strategic perspective and conclude that the development of urban environmental policy is directly linked to the IDP process. According to them, the focus is to integrate sustainability into the IDP process and there is a clear convergence between legal and policy requirements for planning and environmental management present. Du Plessis [15] argues that, despite the recognition of the need for greater alignment of sustainability criteria at all levels of integrated spatial planning, some challenges and shortcomings still remain. This includes the lack of integration of sustainability principles inclusive of the application and/or use of environmental information in IDP and related processes.

With the exception of Geerlings and Stead [2], Stead et al. [3] and May et al. [4], the shortcoming in the abovementioned publications relates to the fact that it only focus on integration between spatial planning and the environment. Waddell [16] broadened the approach towards urban development for land use, transportation and environmental planning. The other authors as discussed, based their focuses on strategic spatial planning based on development instruments (IDP process) [17] and environmental management as included in Retief and Rossouw [14] and Du Plessis [15]. In order for alignment and integration to be inclusive, one should also address the inclusion of transport planning in the process of alignment and integration.

This challenge can in part be addressed by assessing the existing policy and legislative framework and, more specifically, the opportunities created by the Spatial Planning and Land Use Management Act (SPLUMA) [18] and the SPLUMA Regulations [19]. Several policy documents such as the National Transport Master Plan (NATMAP) [20]; the National Development Plan (NDP) [21]; the Draft Integrated Urban Development Framework (DIUDF) [22], and the Draft National Land Transport Strategic Framework (NLTSF) [23] recognize the need for alignment and strategic integration between focuses as dealt with in this chapter.

The principle of sustainable development and the need for improved integration is not a new debate. In its Global Report on Human Settlements (Planning and Design for Sustainable Urban Mobility) [24], the UN Habitat identified the urban mobility challenge and, more specifically, the sustainability challenge to pivot on the integration of land use and transportation planning; social dimensions and reality; environmental dimensions; economic dimensions, as well as institutional and governmental roles and responsibilities. These 
principles are directly and indirectly applied in various sources of UN Habitat 2: International Guidelines on Urban and Territorial Planning [25].

From the Africa perspective consisting of developing countries, the State of the African Cities (UN Habitat, 2014) [26] in its 'Re-imagining sustainable urban transitions' identified integration of factors such as population, urbanization, urban development, urban planning and resource management, urban culture, and green urban development as the main agents for change and development. This implies the involvement of various stakeholders, professions and spheres of government to manage and guide the alignment and integration theme dealt with in this chapter. It is also closely aligned with the focus for UN Habitat 3 [27] on 'The future we want: The city we need' to be held in 2016.

Many role players within the planning domain have realised that there is a delicate balance between environmental, human, economic, institutional, spatial planning and transportation planning to deliver on sustainable development and to promote alignment and integration. This balance is, however, being impacted upon in a negative sense, due to the fact that this relationship is not addressed and reflected on in the application of planning instruments, tools and implementation by all spheres of government and professions involved. Todes et al. [11] and Berrisford and Kihato [8] provide the reasons for this misalignment. It results in impacts such as ecological degradation, widening of development inequality, segregation and compartmentalization of planning, and non-delivery. It also leads to spatial inefficiency and conflicts in planning and development priorities as being experienced in South Africa.

\section{POLICY AND LEGISLATIVE FRAMEWORK GUIDING ALIGNMENT AND INTEGRATION}

Tables 1 and 2 give an overview of the policy and legislative framework guiding alignment and integration in terms of policy and legislative framework as applicable to South Africa. The supporting legal principles underpinning the frameworks are included in Scheepers [28] and Van Wyk [29]. The Berrisford and Kihato's [8] paper is clear on the state of considerable flux that exists in the policy and legislative provisions since democratization in 1994. Transformation from the apartheid system to the democratic system represented many challenges to accommodate change in an orderly and legal fashion.

The complexities in alignment between spheres of government, professions and stakeholders can be deduced from an analysis of the existing policy and legislative framework. This diversity and complexities promote and enhance misalignment, lack of integration, subjective application of planning principles and planning tools, and nondelivery in terms of roles and functions. In order to understand this, the transformation of spatial planning, transportation planning and environmental management within spatial systems should be noted.

\subsection{Influence of spatial planning transformation}

With democratisation in South Africa in 1994, the democratic government inherited a segregated and fragmented spatial system guided by an evenly ineffective policy and legislative framework. The transformation of this framework (notwithstanding several authors referring to the spatial fragmentation consequences of its application by previous political dispensations) commenced with the Draft Green Paper on Development and Planning prepared by the National Development and Planning Commission in 1999 [29]. This was followed by the White Paper on Planning and Land Use Management (RSA, 2001) [5]. 
In context to the guiding principles for alignment and integration included in these documents, it was preceded by the Development Facilitation Act, Act 67 of 1995 [30], as a vehicle to accommodate spatial change and transformation within all spatial systems. Todes et al. [11] conclude that planning in the post-apartheid period focused on facilitation, with an emphasis on reconstruction and development. Planning instruments such as the IDP process (strategic planning) and the introduction of Spatial Development Frameworks (SDFs) as well as other sectoral plans were introduced.

These processes, although it was a step forward, did not resolve the need to transform the legislative realty guiding spatial planning and development in terms of the new democratic needs and expectations. It created new strategic processes with a general requirement for alignment and integration. More emphasis on the need for alignment and integration, is provided for by SPLUMA [18] and its regulations [19].

Researchers such as Dewar et al. [31], Tomlinson [32], Swilling [33], Mabin and Smit [34], PlanAct [35], Tilman and Wall [36] and Harrison et al. [37] have documented the spatial implications of the historical spatial planning and development practices in South Africa.

Since its inception in 2010, the National Planning Commission (NPC) contributed to documenting the effects of the spatial legacy by the formulation of the Diagnostic Overview [38] and strategic (intervention) proposals as contained in the National Development Plan (NDP) [21]. Oranje and Merrifield [39] reported extensively on national spatial development planning in South Africa (1930-2010), while Drewes and Van Aswegen [40] published an overview of the historic process of national planning in South Africa from a temporal perspective. Lessons learnt from these will assist in applying SPLUMA (2013) through promotion of alignment and integration in context to the theme of this chapter.

Spatial development in South Africa can be subdivided into four distinct spatial development phases:

- Phase 1: Urban and rural formation phase (1652 to 1948).

- Phase 2: Urban and rural separation (fragmentation) phase (1948 to 1994).

- Phase 3: Urban re-integration phase and rural development (post-1994 to 2010).

- Phase 4: Spatial system development, reconstruction, integration and consolidation phase (post-2010 to the present).

Of significance in the transformation process related to spatial planning and development was the promulgation of the first new set of democratic laws that serve as a pivotal point to restructure the characteristics of spatial planning in South Africa and the need for alignment and integration. The spatial planning scene changed significantly with the promulgation of the Constitution [1], Municipal Structures Act [41] and the Municipal Systems Act [42]. This resulted in the formulation of Integrated Development Plans (IDPs) (previously Land Development Objectives (LDOs)) for all institutional entities within the municipal spheres of government. The transition and transformation process culminated in the establishment of the National Planning Commission (NPC) in 2011, the National Development Plan (NDP) in 2012 [21], and eventually the approval of SPLUMA (2013) [18] and SPULMA Regulations (2015) [19].

\subsection{Transportation planning transformation to enhance alignment and integration}

Transportation planning in South Africa became a statutory planning activity with the enactment of the Urban Transportation Act 78 of 1977 [43]. Transportation planning, development and management are guided by the core policies and legislative framework. The 
National Land Transport Transition Act (NLTTA) [44] was used until 2009 when the National Land Transport Act [45] and its Regulations [46], [47] were promulgated.

In this context, various policy documents guide the transport planning, transformation and regulating processes: White Paper on National Transport Policy [48]; Moving South Africa (Vision 2020) [49]; Rural Transport Strategy for South Africa [50]; the National Transport Master Plan 2050 (NATMAP 2050) [20], [49] and the Draft National Land Transport Framework (2014) [23]. In 2014/2015, the National Department of Transport (NDoT) commenced with the revision and adaption of NATMAP 2050 by the formulation of a Synopsis Report [51] to address specific components related to alignment, integration and transportation-related system and network issues and components. It includes addressing the interface between the NDP (2012) [21], SPLUMA [18] and NATMAP 2050 [23], [51] and related areas of concern.

\subsection{Environmental management in enhancing alignment and integration}

South Africa was slow to develop and institute formal procedures for environmental assessment. It was only with the enactment of the Environment Conservation Act [52] that provision was made to formulate environmental policy to guide decision-making and to prepare environmental impact reports as pointed out by Sowman et al. [53]. The publication of the document entitled Integrated Environmental Management (IEM) in South Africa (Council for the Environment, 1989) marked the introduction of the concept of environmental management in South Africa. The term IEM was chosen to indicate a general approach that integrates environmental considerations across all stages of the planning and development cycle and would be applicable to policies, programs, plans and projects [54].

The publication of the National Environmental Management Act (NEMA) [55] introduced a new approach to, and role of environmental considerations in development. NEMA provides the framework for co-operative environmental governance in South Africa and promotes the application of environmental assessment and management tools to ensure integrated environmental management of activities. The intention of NEMA was formalized with the publication of the EIA Regulations (2006). On 3 August 2010, the revised NEMA EIA Regulations [56] were promulgated and includes changes to the listing of activities that impact on the use of land as provided for in SPLUMA [18].

\subsection{Need for improved alignment and integration}

In assessing the role of alignment and integration within the context of this chapter, Tables 1 and 2 were compiled. The tables summarise core policies and legislative framework as to assess alignment and integration between spatial planning, transportation planning, and environmental management. Most of the policy and legislative framework provides for the promotion of the principles underlying alignment and integration of functions and processes between all spheres of government although in practice planning, implementation and operative processes are being dealt with in isolation. The lack of delivery within all spatial systems is indicative of failing alignment and integration processes notwithstanding a diverse and detailed policy and legislative framework.

The promulgation of SPLUMA (2013) [18], necessitates that the causes and effects of historic weak alignment on implementation and delivery be assessed. No formal surveys will be carried out, as this chapter focuses on assisting and informing basic knowledge on improving alignment, integration, strategic planning and the application of modelling techniques for improved decision making and delivery. 


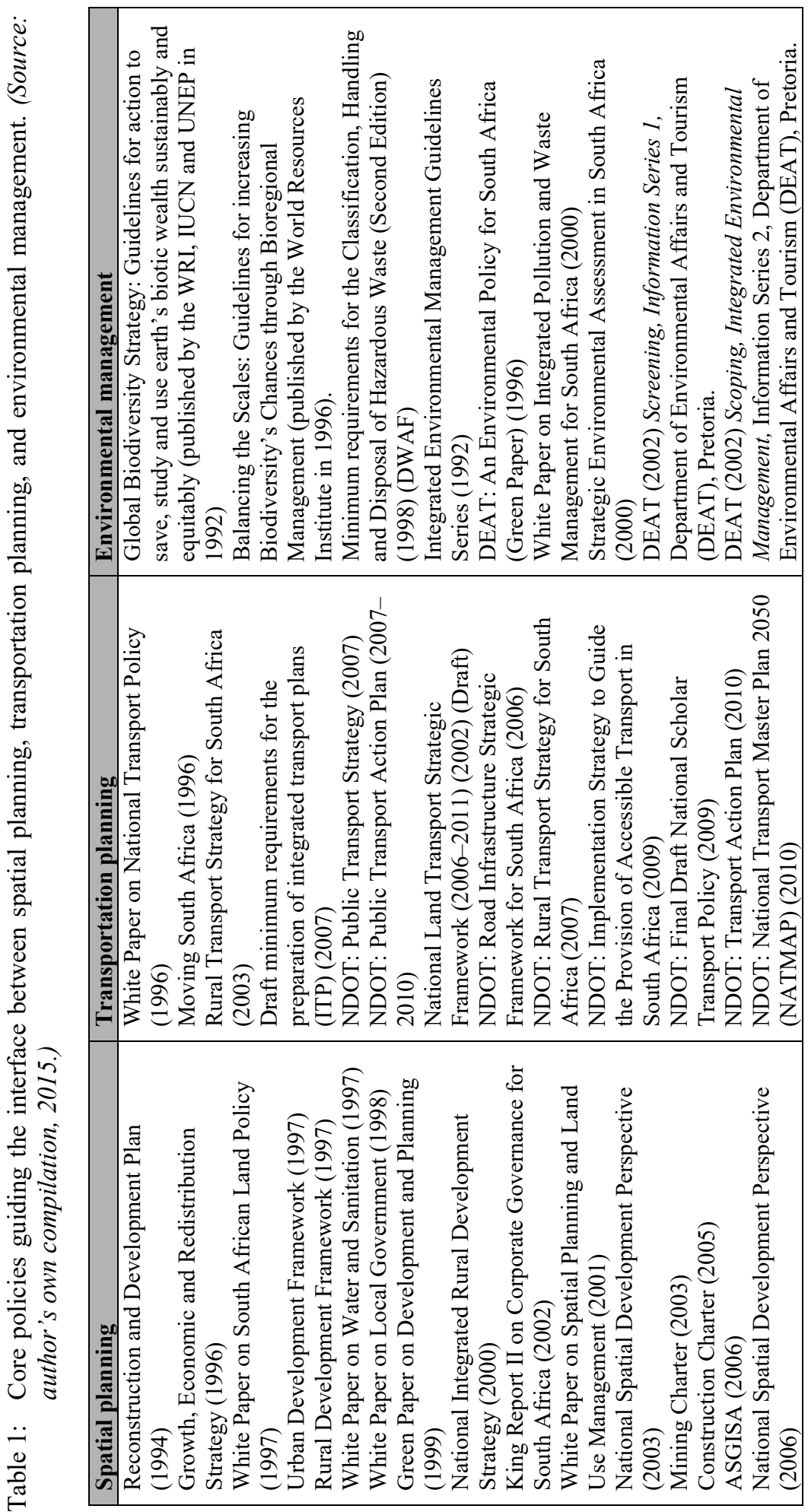




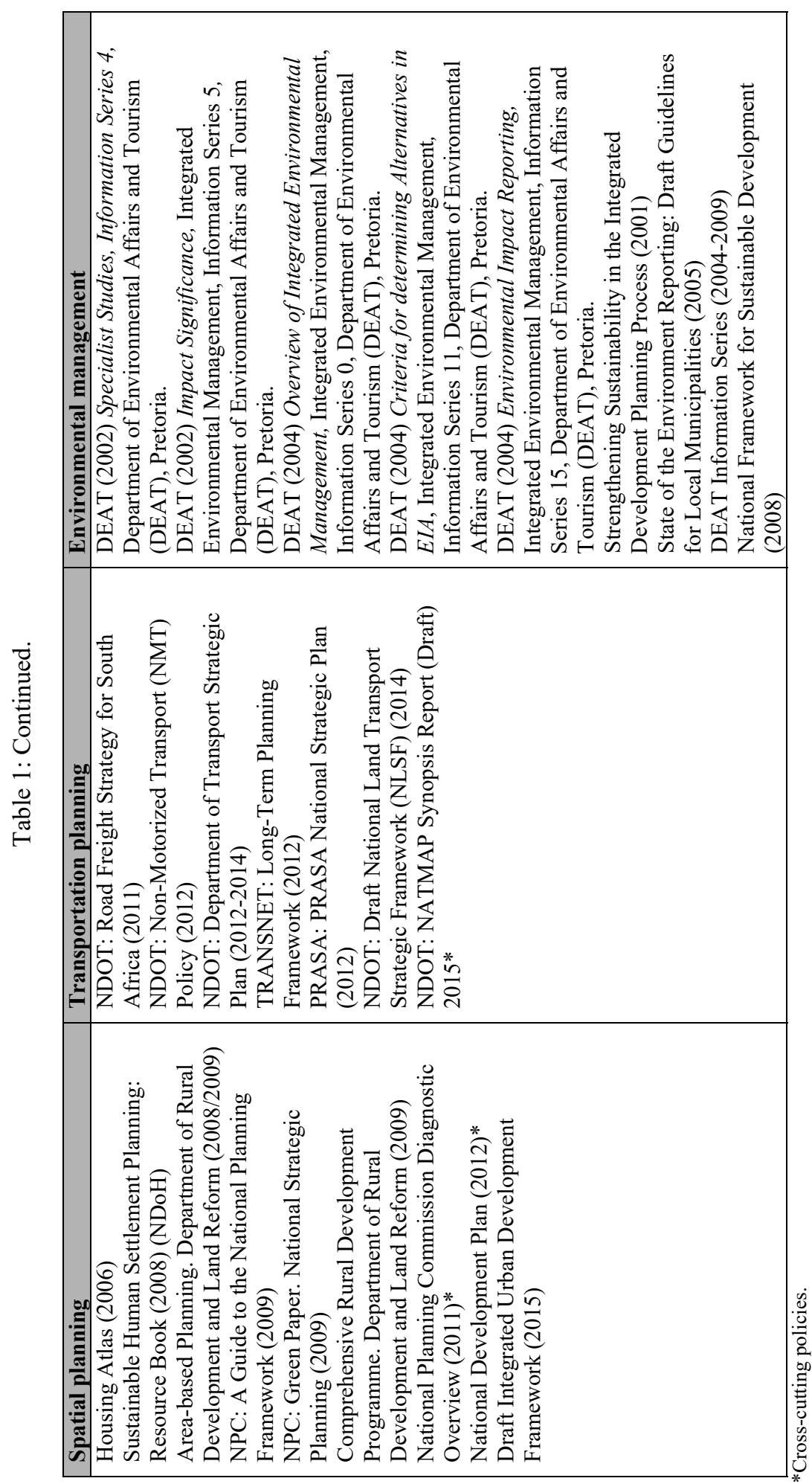




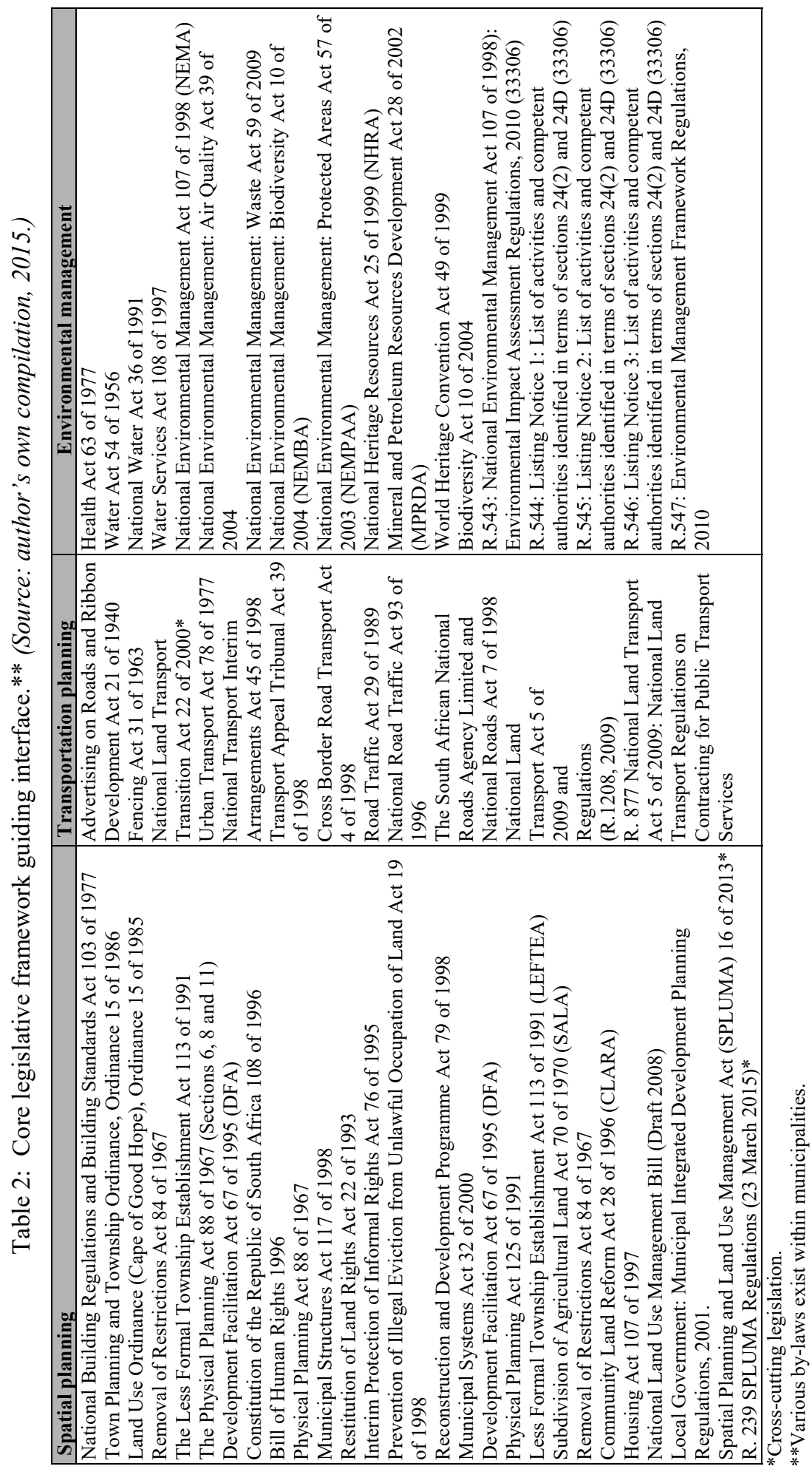


The transformation reality, as summarized above, is indicative of the complexities and challenges in the alignment and integration of the policy and legislative frameworks. This is a well-known area of debate among professionals. Practitioners in these disciplines within the public and private sectors have interpreted the interface for professional and practical reasons differently and alternatively. The evolution over the past decade of policy and legislative frameworks did not necessarily promote a common understanding of the interface between processes.

From an assessment of the content of the policy and legislative framework (Tables 1 and 2 ), it can be concluded that there is restricted provision for the formal alignment and integration of the interface between spatial planning, transportation planning, and environmental management. References to this are very general and sometimes of a purely philosophical nature. This statement should be interpreted with the objectives, as identified in the National Framework for Sustainable Development in South Africa (NFSD) (2008) [57] that makes provision for enhancing systems for integrated planning and implementation; sustaining ecosystems and using natural resources efficiently; economic development via investing in sustainable infrastructure; creating sustainable human settlements, and responding appropriately to emerging human development, economic and environmental challenges.

The provisions contained in SPLUMA [18] and the SPLUMA Regulations [19] provide, inter alia, for the application of specific development principles and norms (Chapter 2); intergovernmental support (Chapter 3); spatial development frameworks (Chapter 4); land-use management (Chapter 5), and land-development management (Chapter 6). These provisions should be interpreted from the alignment and integration debate, as reported on in this chapter. The lessons learned indicate a lack of alignment and integration in terms of the processes that underpin the current policies and legislative framework. Thus far, SPLUMA [18] seems to be a step ahead in the alignment of spatial planning, land use management, and land development.

However, the existing policy and legislative framework (preceding SPLUMA) is classified as complicated, confusing and incomplete. The lack of a comprehensive and overarching guideline document and processes to promote and integrate planning and development as fields of specialization by various foci can clearly be inferred. Much of the alignment within the policy and legislative frameworks is strategic in nature and does not address functional and operational perspectives.

\section{A FRAMEWORK TO MEASURE ALIGNMENT AND INTEGRATION}

SPLUMA [18] provides for the following objectives that are fundamental to enhance alignment and integration:

- To provide for a uniform, effective and comprehensive system of spatial planning and land-use management.

- To ensure that the system of spatial planning and land-use management promotes the social and economic inclusion.

- To provide development principles, norms and standards.

- To provide for sustainable and efficient use of land.

- To provide for co-operative government and intergovernmental relations within all spheres of government.

- To redress imbalances of the past and to ensure equity in spatial development planning and land-use management systems [18]. 
Against this background, Table 3 shows the interface between foci and instruments as provided for in spatial planning, transportation planning, and environmental management policies and legislation (Tables 1 and 2).

In assessing the content of Tables 1,2 and 3, the complexities and need for alignment and integration in planning within all spatial systems are evident. For the purposes of this chapter, it is not only focuses, processes and strategic approaches that need to be aligned and integrated. The effect of such planning and development within the spatial system needs to be assessed as well. Modelling is the appropriate way as to deal with the effect of planning and development in an accountable fashion.

Attaining this goal depends on the sphere of government responsible for the compilation, approval, implementation and monitoring and may include a national department, a provincial department, or a local government. It may also be a concurrent responsibility between different spheres of government. As will be deduced later in this chapter, the availability of data to undertake modelling to quantify and qualify spatial planning proposals and implementations seems to be problematic in developing countries.

\section{IMPACT OF THE DIVISION OF FUNCTIONS, ROLES AND COOPERATION BETWEEN SPHERES OF GOVERNMENT}

The role of government in South Africa is based on functions and obligations allocated to the different spheres in terms of the legislative framework (Table 2), intergovernmental cooperation arrangements and Constitutional Court rulings [58]. From an assessment of the

Table 3: Interface in focus and instruments as provided for in core spatial planning, transportation planning, and environmental management legislation. (Source: author's own compilation from SPLUMA [18], NLTTA [46], NLTA [47] and NEMA [55].)

\begin{tabular}{|c|c|c|}
\hline SPLUMA (2013) & LTTA (2000)/NTA (2009) & (1998) \\
\hline $\begin{array}{l}\text { - Development principles, } \\
\text { norms and standards } \\
\text { - Intergovernmental support } \\
\text { - Spatial Development } \\
\text { Frameworks (SDFs) } \\
\text { - National Spatial Development } \\
\text { Framework (NSDF) } \\
\text { - Provincial Spatial } \\
\text { Development Framework } \\
\text { (PSDF) } \\
\text { - Regional Spatial Development } \\
\text { Framework (RSDF) } \\
\text { - Municipal Spatial } \\
\text { Development Framework } \\
\text { (MSDF) } \\
\text { - Land-Use Management } \\
\text { (LUM) } \\
\text { - Land-Development } \\
\text { Management (LDM) } \\
\text { - Municipal Land-Use Plans } \\
\text { (MLUP) } \\
\text { - Statutory Planning (SP) }\end{array}$ & $\begin{array}{l}\text { - General principles for } \\
\text { transportation planning } \\
\text { - Types of transportation plans } \\
\text { - Provisions on transportation } \\
\text { planning } \\
\text { - National Land Transport } \\
\text { Strategic Framework (NLTSF) } \\
\text { - Provincial Land Transport } \\
\text { Frameworks (PLTF) } \\
\text { - Integrated Transport Plans } \\
\text { (ITPs) } \\
\text { - Freight Transport Plans (FTP) } \\
\text { - Transportation plans and } \\
\text { changes in land use and public } \\
\text { transport infrastructure and } \\
\text { services } \\
\text { - Rationalization of public } \\
\text { transport services } \\
\text { (RATPLANS) } \\
\text { - Public Transport Plans (PTPs) } \\
\text { - Commuter rail plans (CRPs) } \\
\text { - Transport Impact Studies (TISs) } \\
\text { - Traffic Impact Assessments } \\
\text { (TIAs) }\end{array}$ & $\begin{array}{l}\text { - General objectives } \\
\text { - Environmental } \\
\text { Implementation Plans } \\
\text { (EIPs) } \\
\text { - Environmental } \\
\text { Management Plans } \\
\text { (EMPs) } \\
\text { - Integrated Environmental } \\
\text { Management (IEM) } \\
\text { - Environmental Impact } \\
\text { Assessments (EIAs) } \\
\text { - Environmental } \\
\text { - Authorizations (EAs) } \\
\text { - Strategic Environmental } \\
\text { Assessments (SEAs) } \\
\text { - Environmental } \\
\text { Management Programmes } \\
\text { (EMPs) } \\
\text { - Monitoring and } \\
\text { Performance Assessments } \\
\text { (M\&PAs) } \\
\text { - Mine Closure Plans } \\
\text { (MCPs) }\end{array}$ \\
\hline
\end{tabular}


policy and legislation framework, it can be concluded that there are general provisions for the alignment and integration within government and its functions. Provisions for this are contained in the Constitution (1996, Chapter 3, Section 41: 40-41) [1]. The complexities and restrictions in place guiding the division of functions between spheres of government are evident. To understand the division of functions, the obligations to, and roles of co-operative governance should be considered. Cooperative government and intergovernmental relations provide for the following arrangement in terms of alignment and integration:

- To provide and enhance effective, transparent, accountable and coherent government within the national spatial system as a whole.

- To respect and recognize the constitutional status, institutions, powers and functions in all spheres of government.

- To exercise powers and functions conferred on it in terms of the Constitution.

- To exercise the powers and its functions in a manner that does not encroach on the geographical, functional or institutional integrity of any government in another sphere.

- To co-operate with each other in mutual trust and good faith (Constitution, 1996, Chapter 3, Section 41) [1].

The division of functions fulfils an important role as far as alignment and integration are concerned. The role of any sphere of government in terms of functions and the level of responsibility may be classified as strategic, functional, or operational, or any combination thereof.

Several authors contributed further insight into this complex arrangement: National Treasury, Trends in Intergovernmental Finances: 2000/01-2006/07 [59]; Steytler and Fessha, Defining Provincial and Local Government Powers and Functions [60]: The Management of Concurrency (2005); COGTA, Division of Functions (2002) [61] and Van Wyk, Planning in all its (Dis)Guises: Spheres of Government, Functional Areas and Authority [62].

The University of the Western Cape (Community Law Centre) [60] provided a valuable contribution in determining the appropriate functions and powers within local government. Van Wyk [62] concludes that it is an ongoing debate regarding the content of the legislative and executive functional areas relating to 'planning' that are enjoyed by each sphere of government. For alignment and integration to be promoted, the mechanism of cooperative governance must be applied and practiced among all spheres of government. Berrisford and Kihato [8] states specifically that there is a need to create effective intergovernmental communication.

In an effort to simplify the understanding of the complexity of the division of functions, Table 4 was compiled, indicating the core functions and activities allocated to the national, provincial and municipal spheres of government. Table 4 is based on the provisions of the Constitution [1] and the Municipal Structures Act to illustrate the competencies, roles and functions between spheres of government as it was originally intended by the legislator.

Van Wyk [29] points out that Chapter 3 of the Constitution should constantly remind every organ of state, inclusive of every functionary in every sphere of government, of the importance of co-operation, because the principles of co-operation reinforce the values underlying open, transparent and responsible government. Van Wyk further concludes that, in light of the varied functional areas such as agriculture, environment, housing and transport that play a role in planning, the challenge remains to ensure that principles of co-operative government feature significantly at all times. Co-operation remains a constitutional obligation. 
Table 4: Core functions and activities allocated to national, provincial and municipal spheres of government related to spatial planning, transportation planning, and environmental management.*

Powers, functions and/or activities

\begin{tabular}{|c|c|c|c|}
\hline \multicolumn{4}{|c|}{ Powers, functions and/or activities } \\
\hline \multicolumn{4}{|c|}{ Schedule 4: Functional areas of concurrent national and provincial legislative competence (Part A) } \\
\hline Function/activity & National & Provincial & Local \\
\hline Airports other than international and national airports & $\mathrm{x}$ & $\mathrm{x}$ & \\
\hline Environment & $\mathrm{x}$ & $\mathrm{x}$ & \\
\hline Nature conservation & $\mathrm{x}$ & $\mathrm{x}$ & \\
\hline Pollution control & $\mathrm{x}$ & $\mathrm{x}$ & \\
\hline Provincial public enterprises & $\mathrm{x}$ & $\mathrm{x}$ & \\
\hline Public transport & $\mathrm{x}$ & $\mathrm{x}$ & \\
\hline Public works & $\mathrm{x}$ & $\mathrm{x}$ & \\
\hline Regional planning and development & $\mathrm{x}$ & $\mathrm{x}$ & \\
\hline Road traffic regulation & $\mathrm{x}$ & $\mathrm{x}$ & \\
\hline Urban and rural development & $\mathrm{x}$ & $\mathrm{x}$ & \\
\hline Vehicle licensing & $\mathrm{x}$ & $\mathrm{x}$ & \\
\hline \multicolumn{4}{|c|}{ Schedule 4: Functional areas of concurrent national and provincial legislative competence (Part B) } \\
\hline Air pollution & & $\mathrm{x}$ & $\mathrm{x}$ \\
\hline Municipal airports & & $\mathrm{x}$ & $\mathrm{x}$ \\
\hline Municipal planning & & & $\mathrm{x}$ \\
\hline Municipal public transport & & $\mathrm{x}$ & $\mathrm{x}$ \\
\hline Municipal public works & & $\mathrm{x}$ & $\mathrm{x}$ \\
\hline Pontoons, ferries, jetties, piers and harbours & & $\mathrm{x}$ & $\mathrm{x}$ \\
\hline \multicolumn{4}{|c|}{ Schedule 5: Functional areas of exclusive provincial legislative competence (Part A) } \\
\hline Provincial planning & & $\mathrm{x}$ & \\
\hline Provincial roads and traffic & & $\mathrm{x}$ & \\
\hline \multicolumn{4}{|c|}{ Schedule 5: Functional areas of exclusive provincial legislative competence (Part B) } \\
\hline Fences and fencing & & $\mathrm{x}$ & $\mathrm{x}$ \\
\hline Municipal roads & & & $\mathrm{x}$ \\
\hline Noise pollution & & $\mathrm{x}$ & \\
\hline Street trading & & & $\mathrm{x}$ \\
\hline Street lighting & & & $\mathrm{x}$ \\
\hline Traffic and parking & & & $\mathrm{x}$ \\
\hline
\end{tabular}

*1. Functions and activities should be interpreted in terms of concurrent responsibilities, as contained in the applicable legislative framework; 2 . Concept of distinctive, interdependent and interrelated across some functions and activities listed in the Constitution (1996) applies; 3. The rulings of the Constitutional Court as far as powers and functions are concerned, should be consulted; 4 . Functions may cut across spheres of government.

Berrisford and Kihato [8] state that there is uncertainty as to the roles of the three spheres of government. The negative effects resulted from the DFA (1995) and the White Paper on Spatial Planning and Land-Use Management (RSA, 2001) [5] that are now being addressed through SPULMA (2013). It, thus addresses the incomplete work of local government reform in South Africa.

Table 5 shows examples of plans formulated by the different spheres of government in terms of powers, functions, duties and activities dealt with earlier and in terms of the focus of this chapter. 
Table 5: Planning instruments formulated and managed by different spheres of government.*

\begin{tabular}{|c|c|c|c|}
\hline Description/type & National** & Provincial & Local*** \\
\hline \multicolumn{4}{|c|}{ Transportation planning } \\
\hline NATMAP 2050 & $\mathrm{x}$ & & \\
\hline NATMAP 2050 Synopsis Report (2015) & $\mathrm{x}$ & & \\
\hline NLTF (2015) (Draft) & $\mathrm{x}$ & & \\
\hline Public Transport Plans (PTPs) & & $\mathrm{x}$ & $\mathrm{x}$ \\
\hline Commuter Rail Plans (CRPs) & $\mathrm{x}$ & $\mathrm{x}$ & \\
\hline $\begin{array}{l}\text { Rationalization of Public Transportation Services (RAT } \\
\text { Plans) }\end{array}$ & & $\mathrm{x}$ & $\mathrm{x}$ \\
\hline Freight Transport Plans (FTPs) & & $\mathrm{x}$ & $\mathrm{x}$ \\
\hline Transportation Sector Plans (TSPs) & & $\mathrm{x}$ & $\mathrm{x}$ \\
\hline Transportation Infrastructure Plans (TIPs) & $\mathrm{x}$ & $\mathrm{x}$ & $\mathrm{x}$ \\
\hline Traffic Impact Assessments (TIAs) & & & $\mathrm{x}$ \\
\hline Transportation Impact Studies (TIS) & & $\mathrm{x}$ & $\mathrm{x}$ \\
\hline Provincial Land Transport Frameworks (PLTFs) & $\mathrm{x}$ & $\mathrm{x}$ & \\
\hline $\begin{array}{l}\text { National Land Transport Strategic Framework (NLSTF) } \\
(2014)\end{array}$ & $\mathrm{x}$ & $\mathrm{x}$ & \\
\hline Integrated Transport Plans (ITPs) & & $\mathrm{x}$ & $\mathrm{x}$ \\
\hline \multicolumn{4}{|c|}{ Spatial planning } \\
\hline National Spatial Development Plan (NDP) & $\mathrm{x}$ & & \\
\hline National Spatial Development Framework (NSDF) & $\mathrm{x}$ & & \\
\hline Provincial Spatial Development Perspective (PSDP) & $\mathrm{x}$ & $\mathrm{x}$ & \\
\hline Regional Spatial Development Framework (RSDF) & & $\mathrm{x}$ & $\mathrm{x}$ \\
\hline Municipal Spatial Development Frameworks (MSDFs) & & & $\mathrm{x}$ \\
\hline Land-Use Management Systems (LUMS) & & & $\mathrm{x}$ \\
\hline Land Development Management Plans (LDMPs) & & & $\mathrm{x}$ \\
\hline Rural Development Plans (Strategies) (RDPs) & & $\mathrm{x}$ & $\mathrm{x}$ \\
\hline Municipal Regeneration Plans (Urban Renewal, etc.) (MRPs) & & & $\mathrm{x}$ \\
\hline Precinct Plans (PPs) & & & $\mathrm{x}$ \\
\hline Site Development Plans (S.Dev.Ps) & & & $\mathrm{x}$ \\
\hline Integrated Development Plans (IDPs) & & $\mathrm{x}$ & $\mathrm{x}$ \\
\hline Integrated Urban Development Framework (IUDF) & & $\mathrm{x}$ & $\mathrm{x}$ \\
\hline Statutory Planning Processes (SPPs) & & & $\mathrm{x}$ \\
\hline Spatial Development Plans (SDPs) & & $\mathrm{x}$ & $\mathrm{x}$ \\
\hline \multicolumn{4}{|c|}{ Environmental management } \\
\hline Strategic Environmental Assessments (SEAs) & & $\mathrm{x}$ & $\mathrm{x}$ \\
\hline Integrated Environmental Management Plans (IEMPs) & & $\mathrm{x}$ & \\
\hline Environmental Management Plans (EMPs) & & $\mathrm{x}$ & $\mathrm{x}$ \\
\hline Environmental Impact Assessments (EIAs) & & $\mathrm{x}$ & $\mathrm{x}$ \\
\hline Environmental Authorizations (EAs) & & $\mathrm{x}$ & \\
\hline Mine Closure Plans (MCPs) & $\mathrm{x}$ & $\mathrm{x}$ & \\
\hline Environmental Implementation Plans (EIPs) & & $\mathrm{x}$ & $\mathrm{x}$ \\
\hline Environmental Management Programme (EMProg.) & & $\mathrm{x}$ & \\
\hline Monitoring and Performance Assessment Plans (MPAPs) & & $\mathrm{x}$ & $\mathrm{X}$ \\
\hline
\end{tabular}

*Types of plans are generic only. Terminology and content are determined by policies, guidelines and standards.

**May include agencies' concurrent functions with provinces.

***Municipalities are the only sphere of government constitutionally to make and adopt detailed by-laws on landuse management and its other function, as included in the Constitution (1996) and the Municipal Structures Act (1998).

One can infer the need for alignment and integration from Tables 4 and 5. The context should, however, be interpreted in line with Figs 1 and 2. The system complexities, dynamics and need for integration to optimise development within spatial systems are evident. 
Fig. 1 illustrates the vertical and horizontal alignment and integration among the three spheres of government. It shows the organization of the different spheres of government, integration and formulation of planning instruments, structures, institutions and agencies involved. It depicts the basic need to promote cooperative governance through both process and management practices within all spheres of government. Various professions as well as the integration of planning instruments (plans) fulfil a vital role in this instance.

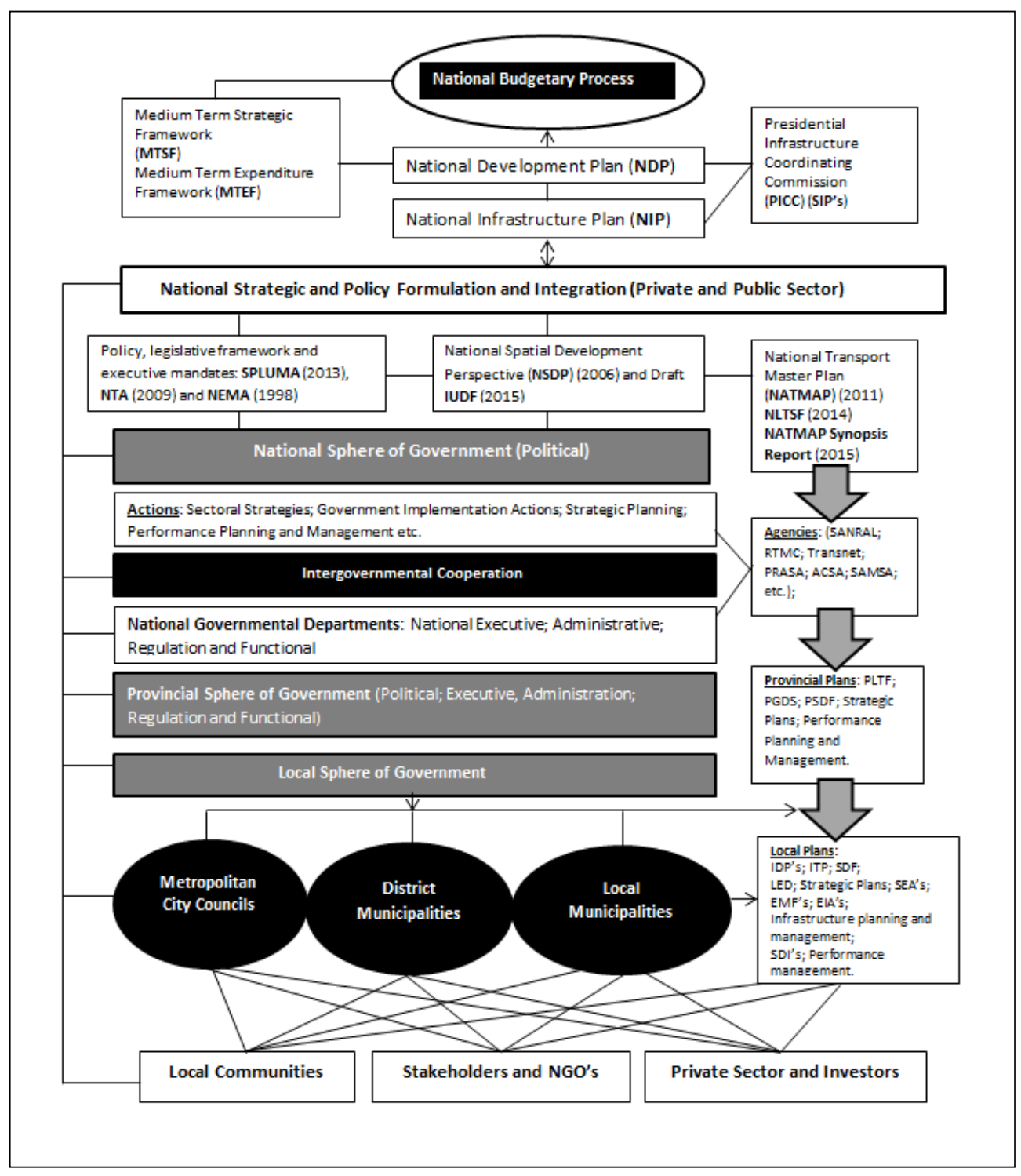

Figure 1: Complexities of alignment and integration between different spheres of government, agencies, co-operation structures and planning instruments. (Source: author's own compilation, 2015.) 


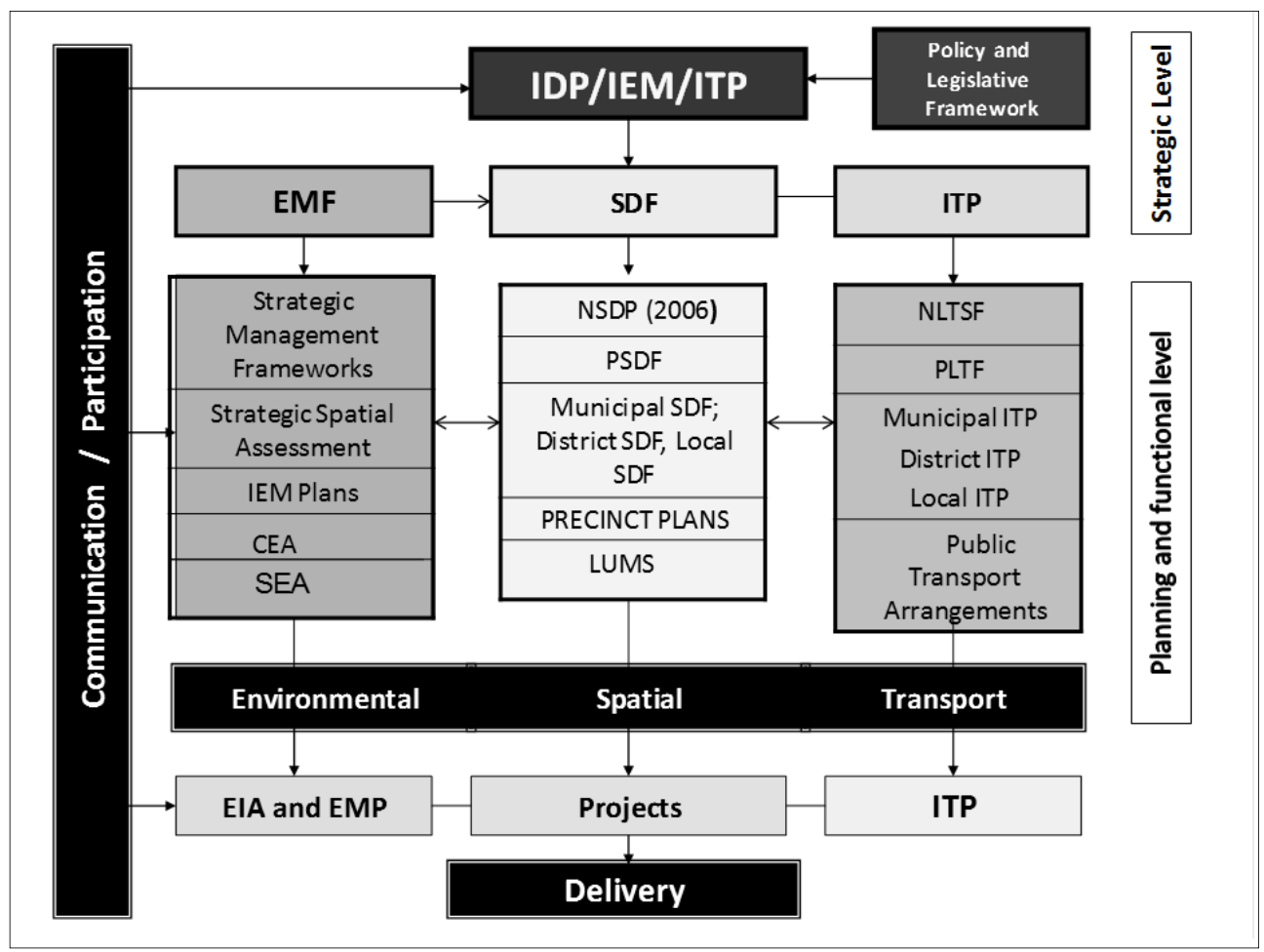

*Implies vertical and horizontal alignment within a municipality as well as with adjacent municipalities. Alignment and integration as provided for in SPLUMA (2013).

Figure 2: Interfaces between IDP, IEM and ITP within municipalities.* (Source: author's own compilation, 2015.)

Malan [63] states that the system of intergovernmental relations and co-operative government in South Africa is rapidly evolving. This is due to the statutory commitment of the various spheres of government to the implementation of the principles of co-operative and intergovernmental relations (refer to Figs 1 and 2).

In terms of section 41: 40-41 of the Constitution (1996) [1] (refer to Fig. 1), government is constituted as national, provincial and local spheres of government: distinctive, interdependent and interrelated. Provision is made for intergovernmental structures such as the Intergovernmental Forum (IGF), the President's Coordinating Council (PCC) and Intergovernmental Relations Committees of Ministers and Provincial Councils (MINMEC); Organized Local Government (SALGA) and Forum for South African Directors-General (FOSAD) (COGTA, 2002) to promote alignment and integration between all spheres of government.

\section{THE DOMAIN OF SPATIAL PLANNING FROM AN ALIGNMENT AND \\ INTEGRATION PERSPECTIVE: ROLE AND IMPACT OF VARIOUS DISCIPLINES Generally, planning (including urban and regional planning, transportation planning, and environmental management) entails the consideration of what can and should happen where, in the spatial systems. It includes the foci and interaction of different policies and practices}


(tools and instruments) across regional space, and sets the role of spaces, places and interaction between professions in a wider context. It goes well beyond 'traditional planning' (inclusive of authorizations) and includes strategic, functional, operational planning and monitoring of all planning and activities. The alignment and integration is related to vertical, horizontal, concentric and three dimensional implications of spatial, transport and environmental on each other. This provides for an ongoing assessment of trans-disciplinary impacts and intervention as to promote sustainable planning and development.

\subsection{Role of education and training in professions and capacity}

Fig. 3 shows the interfaces between fields of education and training for professions involved in the theme of this chapter. The core relationships between subject themes and disciplines are depicted in terms of their orientation from an urban and regional planning perspective.

The relationship between education, training and professional development is fundamental for the way in which alignment and integration is being dealt with in practice and in the workplace. In terms of SPLUMA (2013), planning includes various disciplines, as illustrated in Fig. 3. In some instances, it may imply duplication within certain spheres of government that requires centralization. Co-operation between planning-related and other disciplines is thus a focal consideration in promoting alignment and integration. Todes et al. [11] state that the need for integration may be addressed through:

- Centralizing disciplines such as planning and environmental management.

- Mainstreaming certain concerns and concepts.

- Institutional integration.

- Coordination through improved vertical and horizontal linkages.

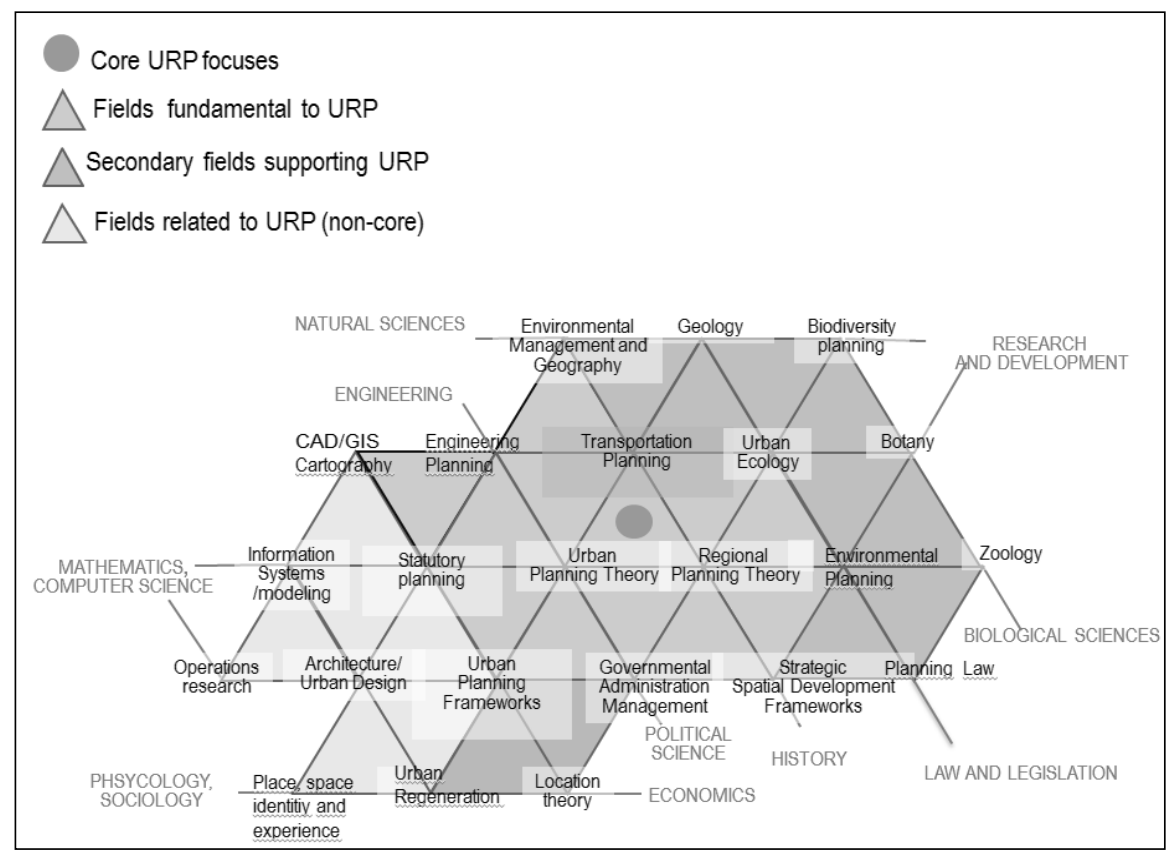

Figure 3: Interfaces in education and training of professions. (Source: Schoeman, 2010 [12].) 
Table 6 shows a classification of the core foci for planning activities based on international and national norms and principles based on the focuses as dealt with in this chapter. The foci are grouped as follows: spatial planning; urban planning; policy and strategy formulation;

Table 6: Core planning foci based on international and national norms and principles. (Source: author's own compilation, 2015.)

\begin{tabular}{|c|c|}
\hline $\begin{array}{l}\text { Core professional planning } \\
\text { focus }\end{array}$ & Domain as interpreted internationally and nationally \\
\hline Spatial planning & $\begin{array}{l}\text { Planning systems; practices in regional space; role of places; strategic } \\
\text { frameworks; forward planning; scale of regional planning; development in } \\
\text { physical environment; spatial plan formulation; impact of migration; } \\
\text { regional spatial planning needs; regional corridor and nodal development. }\end{array}$ \\
\hline Urban planning & $\begin{array}{l}\text { Role of places; anticipating development; scale of urban planning; surface } \\
\text { and beneath surface development; urban development; urban regeneration } \\
\text { and development; urban design; site planning; urban spatial planning needs; } \\
\text { neighbourhood development; urban corridor and activity node } \\
\text { development; urban renewal. }\end{array}$ \\
\hline Policy and strategy formulation & $\begin{array}{l}\text { Interaction of policies; policy interventions; multi-perspective approaches; } \\
\text { disaster preparedness plans; input in drafting of policy and legislation. }\end{array}$ \\
\hline Land-use management & $\begin{array}{l}\text { Land-use planning; land-use management and control; regulating } \\
\text { development; control of land use; management of change in land use; legal } \\
\text { issues related to land use and building codes; legal issues related to } \\
\text { environmental regulations. }\end{array}$ \\
\hline Built environment & $\begin{array}{l}\text { Style of buildings; design of public spaces; conservation of historic } \\
\text { buildings; development of public spaces and places; location, design and } \\
\text { layout of buildings. }\end{array}$ \\
\hline Land availability & Land reservation; identification of land for development. \\
\hline Transportation planning & $\begin{array}{l}\text { Innovative forms of transport; accessibility between places of residence, } \\
\text { work and amenities; traffic congestion management; air pollution } \\
\text { management; transport and land-use models; transportation frameworks. }\end{array}$ \\
\hline Environmental management & $\begin{array}{l}\text { Relationship between built and environment; negative impacts on natural } \\
\text { environment; natural impacts on communities; protection of natural } \\
\text { environments; standard of environmental quality; environmental } \\
\text { sustainability; landscape development; legal issues related to environmental } \\
\text { management. }\end{array}$ \\
\hline $\begin{array}{l}\text { Socio-economic and spatial } \\
\text { development }\end{array}$ & $\begin{array}{l}\text { Social and economic status quo and forecasting; community regeneration; } \\
\text { regional and economic development; rural enterprise; sectoral policies; } \\
\text { planning research; technical analysis; smart growth strategies; economic } \\
\text { development plans; development of resources; socio-economic profiles. }\end{array}$ \\
\hline Facilitation and communication & $\begin{array}{l}\text { Compromise formulation; lead public consultation processes; education, } \\
\text { training and capacity-building; identification of community needs; } \\
\text { community goals and vision compilation; development consultation; public } \\
\text { address, meeting and facilitation. }\end{array}$ \\
\hline Human settlement development & Housing development; housing strategies. \\
\hline Rural development & Community development; area-based planning. \\
\hline Feasibility studies & $\begin{array}{l}\text { Appreciation of spatial complexities; deeper underlying causes; integrated } \\
\text { analysis. }\end{array}$ \\
\hline Implementation & $\begin{array}{l}\text { Infrastructure needs; infrastructure programming; general management; } \\
\text { needs prioritization; implementation and enforcement strategies; } \\
\text { determination of infrastructure and amenities capacity. }\end{array}$ \\
\hline Project management & $\begin{array}{l}\text { Management of programs for planning and implementation; quality } \\
\text { management. }\end{array}$ \\
\hline Infrastructure planning & $\begin{array}{l}\text { Supporting the planning and development of engineering infrastructure } \\
\text { based on sustainable planning policies, practices and needs. }\end{array}$ \\
\hline $\begin{array}{l}\text { Management and analysis } \\
\text { support systems }\end{array}$ & GIS applications and techniques; modelling; systems analysis. \\
\hline
\end{tabular}


land-use management; involvement in the built environment; land availability; transportation planning; environmental management; impact assessments; authorizations; socio-economic and spatial development; facilitation and communication; human settlement development; rural development; feasibility studies; implementation; project management, as well as management and analysis based on the application of decision support systems.

The problematic nature of alignment and integration between specific disciplines originates in the education and training of professionals functioning in these domains. The curricula within these programs do not allow for an understanding of the realities being shared among professions. This creates a professional backlog between professions to reason and debate across professional boundaries from an alignment and integration background. This complicates co-operation, plan formulation, implementation and monitoring.

This implies the need for the revision of the competencies and standards applied in curricula for education and training of professions functioning in such disciplines. This is not only a challenge for higher education institutions, but also implies the role and responsibilities of Professional Councils governing such disciplines. The three foci dealt with in this chapter are being controlled by the following professional councils: South African Council for Planners (SACPLAN) (Planning Professions Act 36 of 2002; Engineering Council of South Africa (ECSA) (Engineering Professions Act 46 of 2000), and the South African Council for Natural Scientific Professions (SACNASP) (Natural Scientific Professions Act 27 of 2003). Todes et al. [11] conclude that "the language used in each profession is not necessarily readily understood by the other". This also applies to the theme of this section.

Capacity within disciplines is also a problem for the majority of professions in South Africa. Disciplines not only consist of professionals, but are also supported by an array of supporting staff with other related and sometimes different qualifications that need to be trained, capacitated and applied in disciplines such as spatial planning, transportation planning, and environmental management. Enhancing alignment and integration thus depends on the dynamic reality inclusive of internalities and externalities being influenced by various professions. To this reality the impact of political will and preferences (notwithstanding the policy and legislative frameworks) complicates the attainment of alignment and integration.

The combination or integration of functions or disciplines alone will not resolve such challenges. The solution lies somewhere between a combination of training and education, extension of competencies and standards for professional registration and provision of adequate capacity in terms of specialization and supporting staff. These resources should be applied in the context of the functions, roles and obligation for government to co-operate, as discussed earlier. Capacity building for politicians within all spheres of government on the need for alignment and integration based on empowerment on the principles guiding the related professions based on the policy and legislative framework need be implemented to ensure alignment and integration as discussed in this chapter.

\section{SPLUMA (2013) AS AN INSTRUMENT TO PROMOTE ALIGNMENT AND INTEGRATION}

The context of addressing the challenge of alignment and integration by SPLUMA [18] is illustrated in Fig. 4, showing the reality to meet the overarching goals and objectives from a sustainability perspective set out in the objectives contained in Chapter 1 of SPLUMA and, specifically, the development principles and norms and standards (Chapter 2).

Table 7 shows the outcome of an alignment and integration analysis based on the provisions of SPLUMA (2013). 


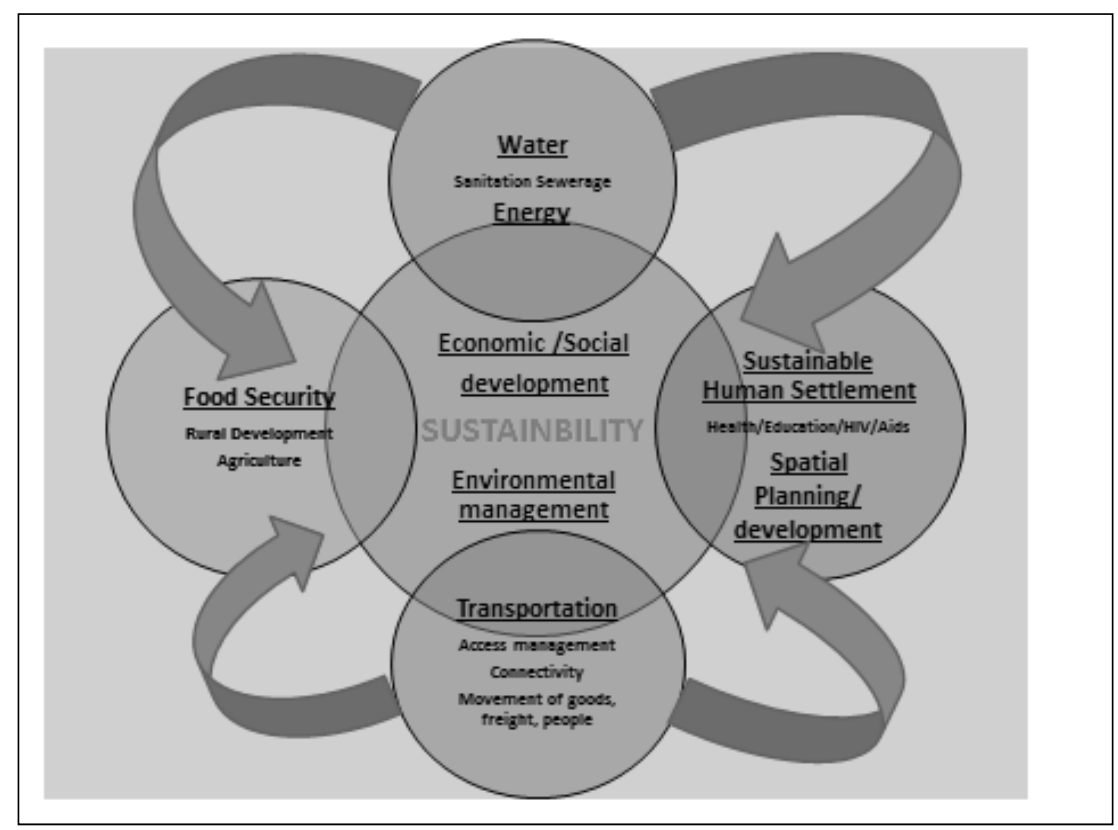

Figure 4: Enhancement of sustainability through alignment and integration by SPLUMA (2013). (Source: author's own compilation, 2015.)

The South African Cities Network [64] summarized SPLUMA as a tool for spatial transformation in a very effective and focused manner by explaining the background, and spatial transformation and by identifying potential spatial transformation levers.

Berrisford and De Visser [65] state that SPLUMA is classified as framework legislation rather than as comprehensive revision of the status quo for land-use management. Berrisford and De Visser (2015) further point out that SPLUMA returns to the planning in the pre-1990s thinking, inclusive of the philosophy 'planning everything'. It relies heavily on SDFs in all spheres of government. It also includes 'wall to wall' land-use management schemes. It is pointed out that the negative effects resulting from the contents of the DFA (1995) [30], White Paper on Spatial Planning and Land-Use Management [5] and Draft Land Use Management Bill [66] are now being addressed through SPLUMA (2013) and its Regulations (2015). It thus addresses the incomplete work of local government planning reform (Berrisford and Kihato [8]).

SPLUMA (2013) recognizes provincial competencies for law-making (Schedule 1 of the Constitution) and specifies the roles (inclusive of intergovernmental support) of national, provincial and municipalities (Chapters 2 to 4). Chapters 5 and 6 deal with land-use management and land-development provisions and arrangements. Section 8 (Norms and Standards) may be determined by the National Minister to allow for consistency across the country. This will promote alignment and integration.

SPLUMA (2013) further operates parallel to other laws. It repeals existing national laws (see Table 7). SPLUMA adds to what the Municipal Systems Act (2000) provides for in terms of the IDPs and SDFs, and it should be noted that SPLUMA does not contradict the MSA (2000) or any other act. 


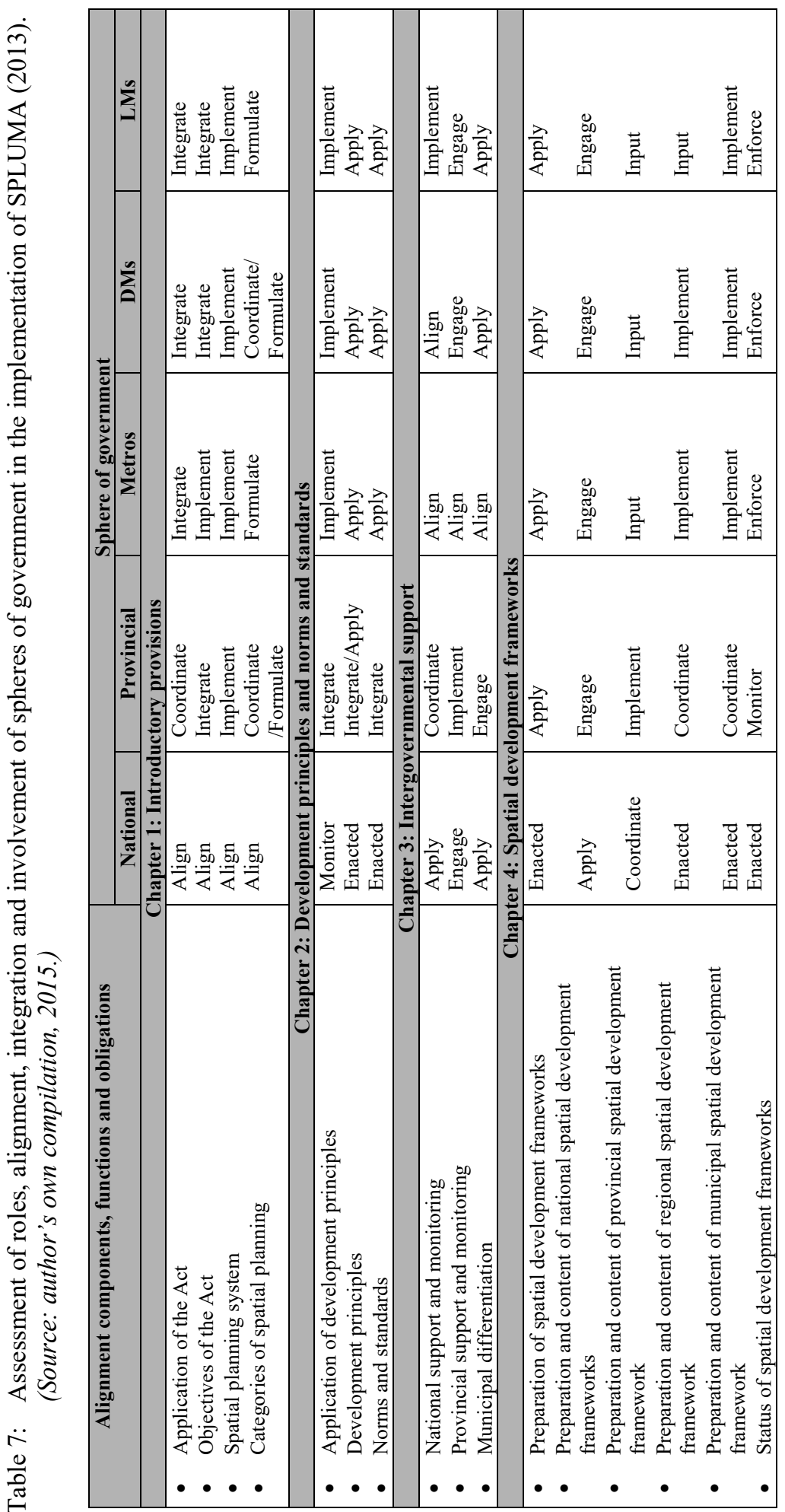




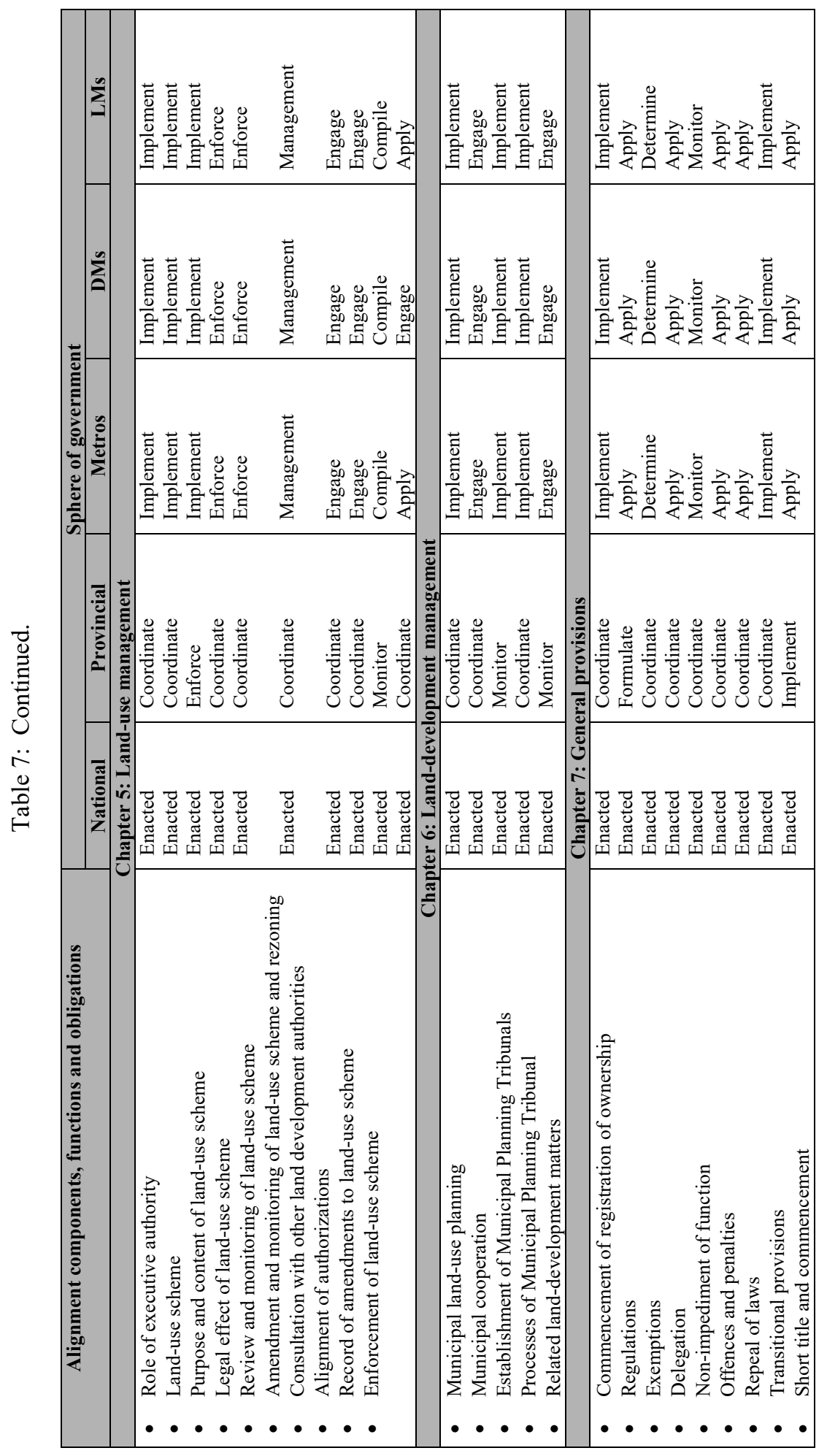




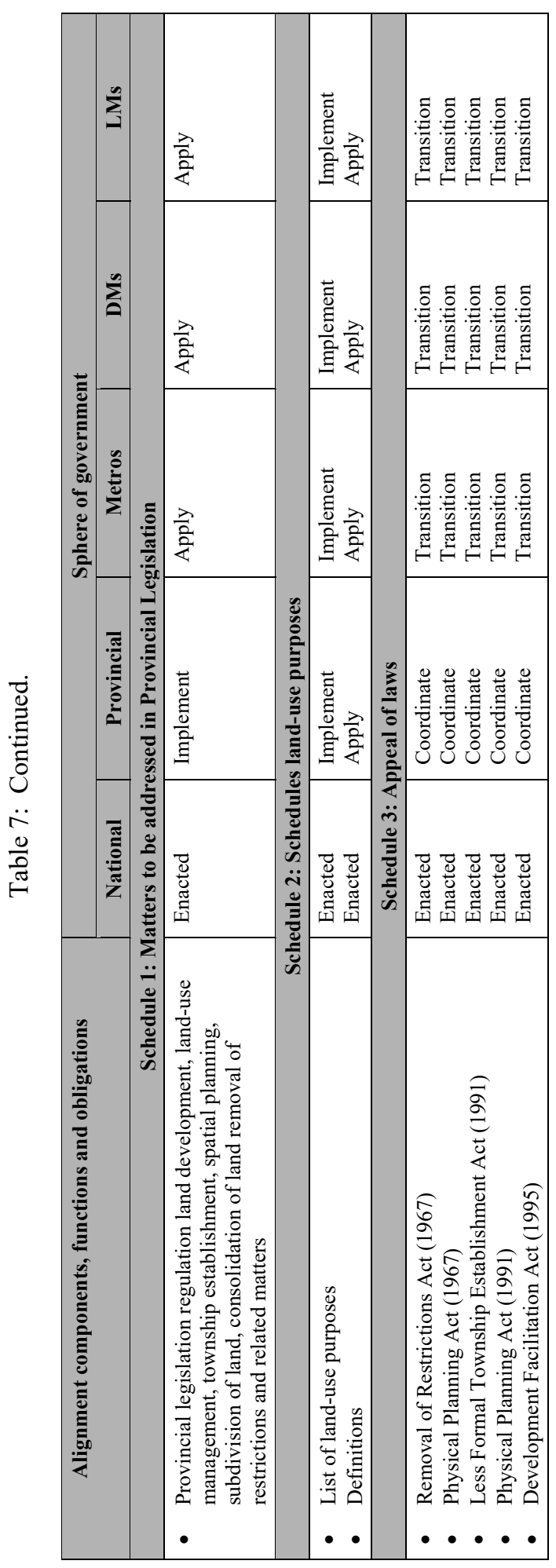




\section{PERSPECTIVES ON STRATEGIC PLANNING AND MODELLING AS MECHANISMS TO GUIDE ALIGNMENT AND INTEGRATION}

The line of argument for improved alignment and integration between spatial planning, transportation planning and environmental management within spatial systems (in both developing and developed countries) is based on the need for a new approach and/or mechanism to promote such goals and objectives. The approaches as formulated by Geerlings and Stead [2], Stead et al. [3] and Stead and Meijers [67] focused on policy development that is applicable to the theme being dealt with in this chapter. However, the complexities in terms of policies directing the focuses in South Africa is much more diverse and complicated (see Table 1 and Table 2) and the line of argument developed in this chapter are based on these complexities.

Strategic planning through integrated development planning applied to South Africa in [17] (an example for other developing countries) provides an applicable framework to deal with such complexities in terms of policies and spatial planning responsibilities such as alignment and integration. Table 8 provides an overview of the content included in the integrated development plan for South Africa to promote alignment and integration [68].

From the assessment of the abovementioned content the absence of sector plans such as an Environmental Management Framework (EMF), Integrated Environmental Management (IEM) and Strategic Environmental Management Assessment (SEA) is evident. This table should also be related to the contents as included in Figs 1 and 2.

Alignment and integration in this context within all other spheres of government is evident and needs to be implemented and coordinated amongst all spheres of government (within the context of planning, identification of needs, prioritization, implementation and operationalization).

This interpretation also needs to be assessed against the following approaches supporting strategic planning as a mechanism to promote alignment and integration:

Albrecht et al. [69] and Albrecht [70] state that in the 1990s the strategic approach to the organization of space at different levels of scale became more prevalent (note: the IDP process in the RSA as discussed above was formalized since 2002). He concludes that 'The 'alternative' strategic planning presented in this paper is conceived as a democratic, open, selective, and dynamic process. It produces a vision to frame problems, challenges, and shortterm actions within a revised democratic tradition'. Albrecht further points out that the strategic process is underlain by the following factors:

- It involves content and process.

- Statics and dynamics.

- Constraints and aspirations.

- The cognitive and the collective, the planned and the learned.

- The socioeconomic and the political.

- The public and the private.

- The vision and the action.

- The local and the global.

- Legitimacy and a revised democratic tradition.

- Values and facts.

- Selectivity and integration ability.

- Equality and power.

- Long term and short term. 


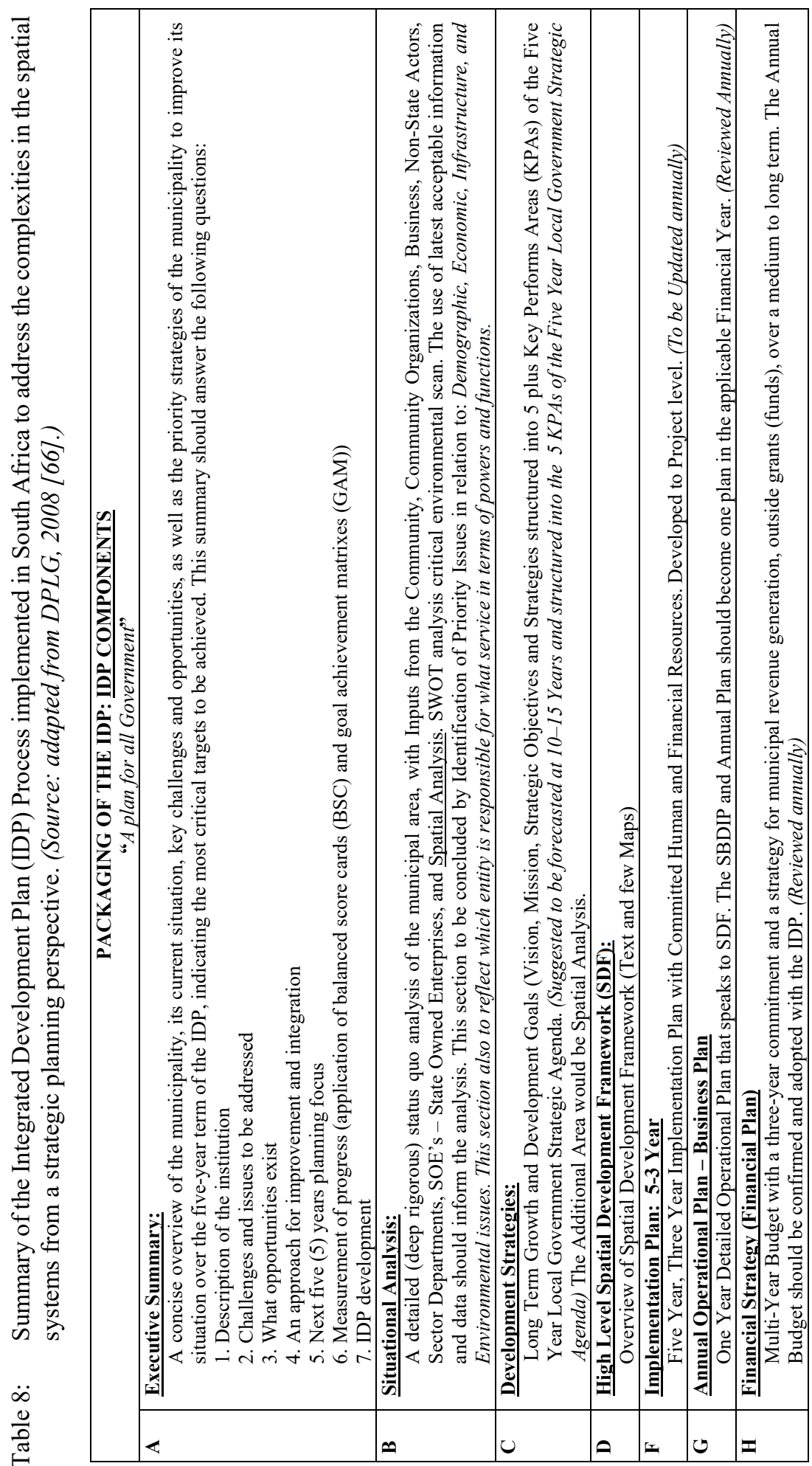




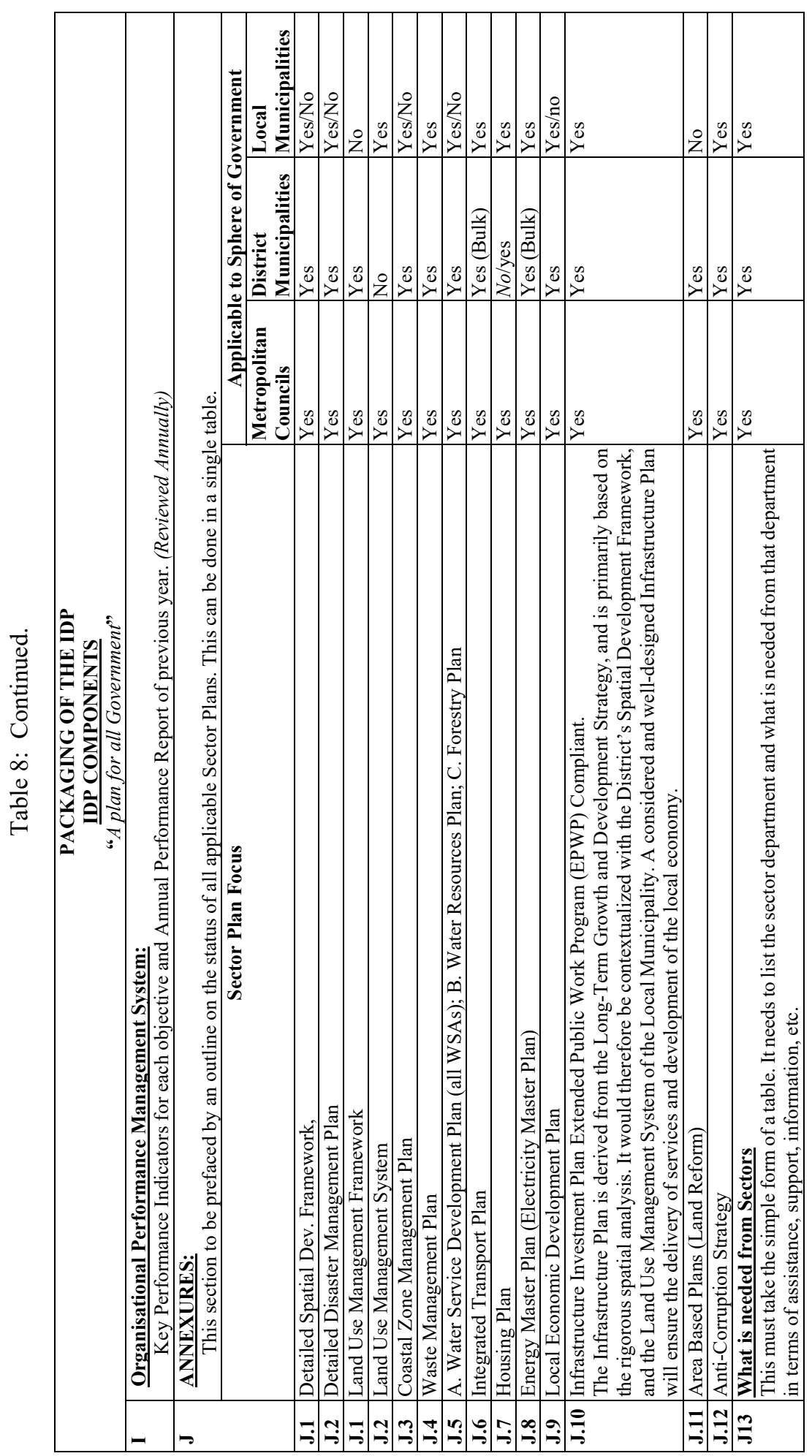


Olesen [71] has taken the debate further to the neo-liberalisation of strategic spatial planning. She states that neo-liberalisation of strategic planning has manifested as a result of governance reforms aiming to reduce or abolish spatial planning at national and regional scales. This is in stark contrast to the need for strategic planning as to integrate transportation and spatial planning as to optimize and enhance alignment and integration to promote delivery and sustainability (Fig. 4). This action is also in contradiction to the application of planning instruments as being dealt with in this chapter.

Modelling as mechanism to enhance alignment and integration refers to the endeavour to enhance the interface through representing the reality of spatial planning, transportation planning and environmental management in an abstract way by relating the focuses of the planning instruments (plans) to each other with the view to predict impacts and long term predictions.

Several authors have reported on integrating the environment in urban planning and environment. The most valuable contribution to this chapter relates to the report published by the United Nations Environmental Programme (UNEP) in 2013 containing key principles and approaches for cities in the twenty-first century [72].

Other publications and approaches more specifically deal with the effects of urban form and/or land use on transportation planning and vice versa [73]-[75]. Related research themes focused on the development of a framework to assist the integration of environmental, social and economic issues in spatial planning [76]. Research related to the question of spatial planning and environmental assessment [77] supports the theme as discussed in this chapter. However, limited specific research thus far focused on the alignment and interface as discussed in context to the line of argument above.

In support of the theme of this chapter, McKenna Davis (Editor) in 2010 [78] published an in-depth case analysis related to green infrastructure. Of significance to the theme of this chapter is the application of mapping for planning from a sustainability perspective.

The best example of modelling complexities in alignment and integration between spatial, transportation and environmental planning and management in support of the abovementioned principles are contained in the work by Waddell in 2011 [79]. He illustrates fundamentally how land use and transportation planning modelling and its challenges in research and practice be approached. He points out that academic research in integrated land use planning and transport is on the rise. This statement by implication links closely to the need for the integration in context to the focus of this chapter. However, alignment and integration consists of much more than to predict outcomes but to optimize space and places in terms of planning, development and delivery. In this the factors of spatial balance, potential realization, continuity and sustainability are the main considerations.

Modelling is basic to strategic planning and decision making and present practices need to be re-engineered as to support the domains of alignment and integration. This will require that the outcome and implications for all disciplines, plans and development focuses be modelled in terms of alternative scenarios and that the related impacts are appropriately quantified and qualified.

Furthermore, to enhance alignment and integration, fundamental changes in management and planning approaches and practices (inclusive of addressing the issue of contradictions, non-alignment of planning processes and duplication in procedures) need to be identified in system wide contexts with the common objective to promote sustainability on transdisciplinary levels.

Waddell [79] identifies the following challenges for integrated modelling:

- Transparency.

- Behavioural validity. 
- Empirical validity.

- Ease of use or simplicity.

- Computational performance.

- Flexibility.

- Data availability and quality.

- Role of uncertainty.

In his article [16], Waddell applies UrbanSim in modelling urban development for land use, transportation and environmental planning. This is possible in developed countries where the addressing of the abovementioned challenges could be met. In developing countries, only some of the attributes used in UrbanSim restricts successful application to asses alignment and integration within the spatial systems. In Chapter 2 the authors show how to overcome these restrictions in a developing country.

This implies the development of a more simplified macro modelling approach to address the challenge of alignment and integration. The methodologies as discussed above need to be applied in an integrated fashion to address the dynamics such as interest of different sphere of government, institutions, stakeholders, values, policies, legislation, guidelines and planning within all spatial systems in an integrated approach.

In developing such a modelling approach the spatial effects of spatial planning, transport planning and environmental management (plans) will have to be applied, quantified and qualified based on a model that are able to optimize spatial alignment, integration and impacts in support of sustainability (Fig. 4).

\section{PERSPECTIVES FROM LESSONS LEARNED}

This chapter discussed the building blocks and therefore the need for improved alignment and integration between spatial, transportation and environmental planning and management and the development processes underpinning each discipline, the policy and legal framework guiding it, the division of powers, the functions, duties and obligations, and the opportunities created by the transformation of the existing policy and legal framework provided for with the promulgation of SPLUMA (2013). This perspective and challenge exist in all developed as well as developing countries in the need to be transparent, avoid duplication and accountable in support of strategic planning and management processes.

Perhaps the greatest area of concern is the processes and conditions related to obtaining land-use rights, development planning considerations, project approval in terms of transportation plans inclusive of traffic impact studies and environmental authorizations. All of these processes impact on optimization of spatial planning based on different strategic planning instruments and synchronizing land use activities.

The complexity of current legislative processes and procedures (as applicable to most developing countries), notwithstanding process transformation provided for by SPLUMA (2013) in the case of South Africa, may cause continued uncertainty among spheres of government and professionals in terms of planning, implementation and project monitoring.

Issues such as how to align, engage, integrate, coordinate, support and implement the formulation of spatial development frameworks, land-use management and development planning processes need to be addressed through formal capacity-building and intensive formal training among all stakeholders and all spheres of government. The implementation of transformation instruments such as SPLUMA (2013) will, however, add to the administrative and professional demand within already under capacitated municipalities. The same applies to other spheres of government within all spatial systems where development challenges need to be addressed effectively and efficiently. To this reality 
political intervention by government in some developing countries may complicate the challenge even further.

The previous spatial and land-use management dispensation in South Africa culminated in the fragmentation of land-use decision-making and requirements, due to the national policy and legislative framework that does not appropriately address the division of functions and powers. Accountability and support in sustainability were thus not reflected and articulated in land-use decisions and environmental authorisations (Kidd, 2008: 85-102). SPLUMA (2013) provides a framework to address the issues of accountability and sustainability. Attention should also be paid to transform all core legislation through amendments in order to promote alignment and integration and not to rely on the provisions guiding co-operative government and intergovernmental relations, as provided for in the Constitution (Act 108 of 1996) only. This challenge also relates to position in other related developing countries and in some cases even to some developed countries.

The promulgation of SPLUMA (2013) and its Regulations (2015) in South Africa directs municipal planning by formalising the role of SDFs within all spheres of government and provides for a new system of land-use management and land development within municipalities. It thus applies to all spheres of government and emphasises the role of municipalities as being the most important sphere of government, as it is closest to the people and communities in terms of delivery. An important focus is the promotion of sustainability in terms of spatial planning, land-use management and land development through alignment and integration.

SPLUMA (2013) thus serves as the interface in promoting alignment and integration within the existing policy and legislative framework guiding planning and development. At this stage, many practitioners view the NDP (2012) as being an ideology that needs the support of instruments such as SDFs within all spheres of government in order to determine what is to happen, where and when. SPLUMA (2013) may assist in this, as it serves as important vehicle for alignment, integration and cooperative governance as a prerequisite for a successful democracy.

Contesting spatial planning, land-use and development-planning issues through the Constitutional Court and/or any Court of Law will result in failure and continuation of the past misalignment, lack of integration, and absence of coordination, resulting in continuing spatial planning inefficiency and non-delivery. This specifically applies to the position in most developing countries.

\section{REFERENCES}

[1] Republic of South Africa (RSA), Constitution of the Republic of South Africa, Act 108 of 1996, Government Printer: Pretoria, 1996.

[2] Geerlings, H. \& Stead, D., The integration of land-use planning, transport and environment in European policy and research. Transport Policy, 10(3), pp. 187-196, 2003.

[3] Stead, D., Geerlings, H. \& Meijers, E., Integrated land-use planning and environmental policy: An international comparison, Volume 1. OTB Research Institute for the Built Environment, Delft University for Technology: Rotterdam, 2003.

[4] May, A.D., Jopson, A.F. \& Mathews, B., Research challenges in urban transport policy. Transport Policy, 10(3), pp. 157-164, 2003.

[5] Republic of South Africa (RSA), White Paper on Spatial Planning and Land-Use Management, Government Printer: Pretoria (refer also to the Drafts for 2003, 2006 and 2007), 2001. 
[6] Claasens, P.E., The role of environmental management (spatial planning, development planning and conservation of the natural environment) in prompting sustainable development. Report to the National Research Foundation, Pretoria, 2003.

[7] Sowman, M. \& Brown, A.L., Mainstreaming environmental sustainability into South Africa's integrated development planning process. Journal for Environmental Planning and Management, 49(5), pp. 695-712, 2007.

[8] Berrisford, S. \& Kihato, M., Local government planning legal frameworks and regulatory tools: Vital signs? Consolidating Developmental Local Government. Lessons from the South African Experience, eds M. Van Donk, M. Swilling, E. Pieterse \& E. Parnell, ISANDLA Institute, UCT Press: Cape Town, pp. 51-75, 2008.

[9] Sowman, M., Integrating environmental sustainability issues into local government planning and decision-making processes. Democratising Local Government: The South African Experiment, eds S. Parnell, E. Pieterse, M. Swilling \& D. Wooldridge, University of Cape Town Press, Cape Town, pp. 181-203, 2002.

[10] Todes, A., Regional planning and sustainability: Limits and potentials of South Africa's integrated development plans. Journal of Environmental Planning and Management, 47(6), pp. 843-861, 2004.

[11] Todes, A., Sim, V. \& Sutherland, C., The relationship between planning and environmental management in South Africa: The case of KwaZulu-Natal. Planning Practice and Research, 24(4), pp. 411-433, 2009.

[12] Schoeman, C.B., Urban and regional planning and the interface with environmental management and transportation planning. Inaugural address. No. 238, Scientific Contributions, North-West University, Potchefstroom Campus, 2010.

[13] Vigar, A., Healey, P., Hull, A. \& Davodi, S., Planning Governance and Spatial Strategy in Britain. An Institutional Analysis, Macmillan: London, 2000.

[14] Retief, F. \& Rossouw, N., Urban environmental policy in Africa. International Handbook of Urban Policy, Volume 1: Contentious Global Issues, ed. H.S. Geyer, Edwin Elgar Publishing Limited: Cheltenham, pp. 288-306, 2007.

[15] Du Plessis, D.J. A critical reflection on urban spatial planning practices in postapartheid South Africa. Urban Forum, 25(1), pp. 68-88, 2014.

[16] Waddell, P., Modelling urban development for land use, transportation, and environmental planning. Journal of the American Planning Association, 68(3), pp. 297-314, 2002.

[17] Department of Local Government and Gtz, IDP Guide Pack. Guide III-Methodology, Departmental Publication, Pretoria, 2002.

[18] Republic of South Africa (RSA), Spatial Planning and Land-Use Management (SPLUMA) Act, Act 16 of 2013, Government Printer: Pretoria, 2013.

[19] Republic of South Africa (RSA), Regulations in Terms of the Spatial Planning and Land-Use Management (SPLUMA) Act (16 of 2013)/(R.239), 23 March 2015, Government Printer: Pretoria, 2015.

[20] National Department of Transport. National Transport Master Plan. Departmental publication, Pretoria, 2011.

[21] National Planning Commission (NPC), National Development Plan. NPC. Internal Publication, Pretoria. Online. www.gov.za/issues/national-development-plan-2030, 2012.

[22] Department of Cooperative Governance and Traditional Affairs (COGTA), Draft integrated urban development framework, Pretoria, 2014.

[23] National Department of Transport, Draft National Transport Strategic Framework, Departmental Publication, Pretoria, 2014. 
[24] United Nations Habitat (UN HABITAT), Planning and design for sustainable urban mobility. Global Report on Human Settlements 2013, Nairobi, Kenya, 2013.

[25] United Nations Habitat (UN HABITAT), Towards the development of international guidelines on urban and territorial planning. Nairobi, Kenya, 2014.

[26] United Nations Habitat (UN HABITAT), The state of African cities. Re-imagining sustainable urban transitions. Nairobi, Kenya, 2014.

[27] United Nations Habitat (UN HABITAT), Habitat III: The future we want: The city we need. Nairobi, Kenya, 2014.

[28] Scheepers, T., A Practical Guide to Law and Development in South Africa. An Introduction to the Law Applicable to the Development Management Process in South Africa, Juta: Kenwyn, 2000.

[29] Van Wyk, J., Planning Law, 2nd ed., Juta: Cape Town, 2012.

[30] Republic of South Africa (RSA), Development Facilitation Act, Act 67 of 1995. Government Printer: Pretoria, 1995.

[31] Dewar, D., Todes, V.\& Watson, V., Industrial decentralization policy as a mechanism for regional development in South Africa; its premises and record. Urban Problems Research Unit: Project Report. University of Cape Town, Cape Town, 1984.

[32] Tomlinson, R., Urbanization in Post-Apartheid South Africa, Unwin Hyman: London, 1990.

[33] Swilling, M., Introduction. Apartheid City in Transition, eds M. Swilling, R. Humphries \& K. Shubane, Oxford University Press: Cape Town, p. viii, 1991.

[34] Mabin, A. \& Smit, D., Reconstructing South African cities? The making of urban planning 1900-2000. Planning Perspectives, 12(2), pp. 193-223, 1997.

[35] PlanAct, Integrated Development Planning - A Manual for Community Leaders, Aloe Publications: Braamfontein, Johannesburg, 1997.

[36] Tilman, H. \& Wall, R., Urbanization and housing in South Africa. Housing Generator - Integration or Fragmentation, ed. H. Tilman, NAI Publishers, e-book: Rotterdam, 1997.

[37] Harrison, P., Huchzermeyer, M. \& Mayekiso, M. (eds), Confronting Fragmentation: Housing and Urban Development in a Democratising Society, University of Cape Town Press: Cape Town, 2003.

[38] National Planning Commission (NPC), Diagnostic Overview. NPC Pretoria, Online. www.gov.za/sites/www.gov.za, 2011.

[39] Oranje, M. \& Merrifield, A., National spatial planning in South Africa 1930-2010: An introductory comparative analysis. Town and Regional Planning, 56, pp. 29-45, 2010.

[40] Drewes, J.E. \& Van Aswegen, M., National planning in South Africa: A temporal perspective. Town and Regional Planning, 62(2013), pp. 21-28, 2013.

[41] Republic of South Africa (RSA), Local Government: Municipal Structures Act, Act 117 of 1998, Government Printer: Pretoria, 1998.

[42] Republic of South Africa (RSA), Local Government: Municipal Systems Act, Act 32 of 2000, Government Printer: Pretoria, 2000.

[43] Republic of South Africa (RSA), Urban Transport Act, Act 78 of 1977, Government Printer: Pretoria, 1977.

[44] Republic of South Africa (RSA), National Land Transport Transition Act, Act 22 of 2002, Government Printer: Pretoria, 2000.

[45] Republic of South Africa (RSA), National Land Transport Act, Act 5 of 2009, Government Printer: Pretoria, 2009.

[46] Republic of South Africa (RSA), R.1208 National Land Transport Act (5/2009): National Land Transport Regulations, Government Printer: Pretoria, 2009. 
[47] Republic of South Africa (RSA), R.877 National Land Transport Act (5/2009): National Land Transport Regulations on Contracting for Public Transport Services, Government Printer: Pretoria, 2009.

[48] Republic of South Africa (RSA), White Paper on National Transport Policy, Government Printer: Pretoria, 1996.

[49] Republic of South Africa (RSA), Moving South Africa - The Action Agenda, Departmental Publication: Pretoria, 1999.

[50] Republic of South Africa (RSA), Rural Transport Strategy for South Africa, Departmental Publication: Pretoria, 2003.

[51] National Department of Transport, Draft NATMAP 2050 Synopsis Report. Unpublished Departmental Report, Pretoria, 2015.

[52] Republic of South Africa (RSA), Environment Conservation Act, Act 73 of 1989, Government Printer: Pretoria, 1989.

[53] Sowman, R., Fuggle, R. \& Preston, G., A review of the evolution of environmental evaluation procedures in South Africa. Environmental Impact Assessment Review, 15, pp. 45-67, 1995.

[54] Council for the Environment. Integrated Environmental Management in South Africa, Joan Lotter Publications: Pretoria, 1989.

[55] Republic of South Africa (RSA), National Environmental Management Act, Act 107 of 1998, Government Printer: Pretoria, 1998.

[56] Republic of South Africa (RSA), Regulations in terms of Chapter 5 of the National Environmental Management Act, 1998. Regulations R.543 to R.547, Government Printer: Pretoria, 2010.

[57] Department for Environmental Affairs and Tourism, A National Framework for Sustainable Development in South Africa, Departmental Publication: Pretoria, 2008.

[58] Constitutional Court Ruling, City of Johannesburg Metropolitan Municipality (Applicant), Gauteng Development Tribunal (First Respondent), Gauteng Development Appeal Tribunal (Second Respondent) and Ivory-Palms Properties 20 CC (Third Respondent), 2010.

[59] National Treasury, Departmental Publication 2000/01-2006/07, Pretoria.

[60] University of the Western Cape, Community Law Centre, Developmental local government: Determining appropriate functions and powers. Local Government Project, Cape Town, 2007.

[61] Department of Cooperative Governance and Traditional Affairs, Divisions of Functions. Departmental Publication: Pretoria, 2002.

[62] Van Wyk, J., Planning in all its (dis)guises: Spheres of government, functional areas and authority. PER/PLJ, 15(5), pp. 288-318, 2012.

[63] Malan, L., Intergovernmental relations and co-operative government in South Africa: The ten-year review. Politea, 24(2), pp. 226-243, 2005.

[64] South African Cities Network, SPLUMA as a tool for spatial transformation, Braamfontein, sacitiesnetwork.co.za, 2015.

[65] Berrisford, S. \& De Visser, J., UCT CPD Programme: Lectures on preparing for SPLUMA implementation in co-operation with MCA planners, Cape Town, 2015.

[66] Republic of South Africa (RSA), Final Draft Land-Use Management Bill, Government Printer: Pretoria, 2008.

[67] Stead, D. \& Meijers, E., Policy integration in practice: Some experiences of integrating transport, land-use planning and environmental policies in local government. Berlin Conference on the Human Dimensions of Global Environmental Change: Greening of Policies-Linkages and Policy Integration, Conference Proceedings, 2004. 
[68] Department of Provincial Local Government, Integrated Development Plan (IDP) Format Guide, Departmental Publication: Pretoria, 2008.

[69] Albrecht, L., Healey, P., \& Kunzman, R., Strategic planning and regional governance in Europe. $A P A, \mathbf{6 9}(2), 2003$.

[70] Albrecht, L., Strategic (spatial) planning re-examined. Environmental and Planning B; Planning and Design, 31, pp. 743-758, 2004.

[71] Olesen, K., The neoliberalisation of strategic spatial planning. Planning Theory, 13(3), 2014.

[72] United Nations Environment Programme (UNEP), Integrating the environment in urban planning and management-key principles and approaches for cities in the 21st Century, Nairobi, Kenya, 2013.

[73] Iacono, M., Levinson, D. \& El-Geneidy, A., Models of transportation and land use change: A guide to the territory. Journal of Planning Literature, SAGE Publications, 2008.

[74] Sivakumar, A., Modelling Transport: A Synthesis of Transport Modelling Methodologies, Imperial College London: London, 2007.

[75] Giuliano, G., New directions for understanding transportation and land use. Environment and Planning A, 21, pp. 145-159, 1989.

[76] Eggenberger, M. \& Partiario, R., Development of a framework to assist the integration of environmental, social and economic issues in spatial planning. Impact Assessment and Project Appraisal, 18(3), pp. 201-207, 2000.

[77] Goodstadt, V. \& Partidaro, M.R., Spatial Planning and Environmental Assessments. Department of Environmental Affairs. Part III: The Practice. TEEB for local and regional decision makers. https://www.environment.gov.za/.../economicsof_eco systems spatialplanning_enviroassessment.pdf, pp. 105-123, 2010.

[78] Davis, M., Green Infrastructure In-Depth Case Analysis: Theme 7: Mapping for Planning. IEEP, Ecologic, GHK, TAU, University of Antwerp, VITO, 2010.

[79] Waddell, P., Integrated land use and transportation planning and modelling: Addressing the challenges in research and practice. Transport Reviews, 31(2), pp. 209-229, 2011. 